\title{
Integration of Aspergillus niger transcriptomic profile with metabolic model identifies potential targets to optimise citric acid production from lignocellulosic hydrolysate
}

\author{
Daniel J. Upton ${ }^{1 *}$ D, Mehak Kaushal ${ }^{2}$, Caragh Whitehead ${ }^{1}$, Laura Faas ${ }^{1}$, Leonardo D. Gomez ${ }^{1}$, \\ Simon J. McQueen-Mason', Shireesh Srivastava² and A. Jamie Wood ${ }^{1,3}$
}

\begin{abstract}
Background: Citric acid is typically produced industrially by Aspergillus niger-mediated fermentation of a sucrosebased feedstock, such as molasses. The fungus Aspergillus niger has the potential to utilise lignocellulosic biomass, such as bagasse, for industrial-scale citric acid production, but realising this potential requires strain optimisation. Systems biology can accelerate strain engineering by systematic target identification, facilitated by methods for the integration of omics data into a high-quality metabolic model. In this work, we perform transcriptomic analysis to determine the temporal expression changes during fermentation of bagasse hydrolysate and develop an evolutionary algorithm to integrate the transcriptomic data with the available metabolic model to identify potential targets for strain engineering.

Results: The novel integrated procedure matures our understanding of suboptimal citric acid production and reveals potential targets for strain engineering, including targets consistent with the literature such as the up-regulation of citrate export and pyruvate carboxylase as well as novel targets such as the down-regulation of inorganic diphosphatase.

Conclusions: In this study, we demonstrate the production of citric acid from lignocellulosic hydrolysate and show how transcriptomic data across multiple timepoints can be coupled with evolutionary and metabolic modelling to identify potential targets for further engineering to maximise productivity from a chosen feedstock. The in silico strategies employed in this study can be applied to other biotechnological goals, assisting efforts to harness the potential of microorganisms for bio-based production of valuable chemicals.
\end{abstract}

Keywords: Fermentation, Citric acid, Aspergillus niger, Metabolic modelling, Transcriptomics

\section{Background}

For a century, the filamentous fungus Aspergillus niger has been used industrially for the production of citric acid; currently, production exceeds 2 million tonnes

\footnotetext{
*Correspondence: daniel.upton@york.ac.uk

${ }^{1}$ Department of Biology, University of York, Wentworth Way, York YO10 5DD, UK
}

Full list of author information is available at the end of the article a year [1]. The ease of culture and its tolerance to typical industrial fermentation stresses make $A$. niger [2] a desirable organism for industrial applications. Beyond its established uses, $A$. niger also has potential to produce other valuable chemicals including succinic [3] and itaconic acid [4].

The commercial production of citric acid by A. niger fermentation is dependent on sucrose-based feedstocks, primarily molasses [5]. In this regard, $A$. niger is 
underexploited as it is saprophytic in nature with an ability to assimilate at least 69 carbon sources and 30 nitrogen sources [6]. There is an increasing need to unlock this metabolic potential, so that $A$. niger can play a key role in harnessing the value of underutilised second-generation feedstocks for the bioeconomy [7]. One such feedstock is sugarcane bagasse, the main by-product of sugarcane processing and a potential source of lignocellulosic sugars. Global sugarcane production was around 1900 million tonnes in 2013 [8], generating around half a billion tonnes of bagasse. To achieve cost-competitive citric acid production from bagasse hydrolysate requires the optimisation of strains away from sucrose-based fermentation to bagasse hydrolysate as the fermentation medium.

Strain optimisation can be achieved either via cycles of random mutagenesis and selection or by targeted engineering. The former is well demonstrated for citric acid production by $A$. niger [9], and although successful, its iterative nature makes it laborious and requires a suitable selection and evolution strategy to be available or designed. Rational strain engineering provides a faster strain development process that achieves the required genetic changes in a more stable manner. Optimising strains via targeted engineering is dependent on a metabolic understanding of the target organism and an ability to accurately identify targets. The establishment of omics technologies has enabled researchers to develop a more comprehensive understanding of the target organism; however, this can be challenging given the volume of data from omics analyses. One core systems biology method, constraint-based metabolic modelling, has now developed an extraordinary number of differing methods to address this challenge and integrate omics data with metabolic models [10-16].

In this study, we highlight the potential of bagasse as a feedstock for citric acid production, examining the performance of $A$. niger for the fermentation of bagasse hydrolysate to citric acid. Using fermentative time series data, we adapted our dynamic model [17] to capture the dynamics of bagasse hydrolysate fermentation. We show that the performance of the strain in this study is suboptimal and investigate further using transcriptome analysis at key fermentation timepoints. By employing a novel method involving an evolutionary algorithm guided by transcriptome data, we identify targets to achieve optimal citric acid productivity from bagasse hydrolysate.

\section{Results}

\section{Fermenting sugarcane bagasse hydrolysate to produce citric acid}

To evaluate the fermentation of sugarcane bagasse hydrolysate for the production of citric acid, we obtained fermentative time series data on citric and biomass output as well as glucose, xylose, and phosphate input. From a hydrolysate containing $120 \mathrm{~g} / \mathrm{L}$ total sugars consisting of glucose $(80 \mathrm{~g} / \mathrm{L})$ and xylose $(40 \mathrm{~g} / \mathrm{L}), 50 \mathrm{~g} / \mathrm{L}$ citric acid was produced in 6 days (Fig. 1). Glucose was fully consumed by day 5 at which point xylose consumption increased significantly with full consumption of sugars by day 7 , indicating a sequential uptake mechanism. We observed similar characteristics to citric acid fermentations performed previously [17] with the onset of citric acid production coinciding with the full depletion of external phosphate and a switch to phosphate-limited growth.

\section{Simulating the fermentation of sugarcane bagasse hydrolysate to citric acid by dynamic modelling}

To capture the dynamics of sugarcane bagasse hydrolysate fermentation in silico, we adapted our dynamic modelling framework [17] to reflect mixed glucose/xylose fermentations. The adapted model simulates the sequential uptake of glucose and xylose and with adjustments made to kinetic parameters (see Methods) gives close fits to the in vivo fermentation data (Fig. 1). The model estimated that citric acid titres could reach a maximum of $85 \mathrm{~g} / \mathrm{L}$, almost twofold higher than what we observed in vivo (Fig. 1). By imposing a constraint on citric acid output in silico, the model was able to reflect in vivo citric acid production (Fig. 1), suggesting the strain we used is suboptimal and highlighting the need for strain optimisation to realise optimal productivity.

\section{Transcriptomic analysis at selected timepoints to investigate the fermentation of sugarcane bagasse hydrolysate to citric acid}

To extend our investigation, we performed transcriptomic analysis at three key fermentation timepoints (Fig. 1). The first timepoint (T1) was taken, while external phosphate was still present before the onset of citric acid production and phosphate-limited growth. The other two timepoints (T2 and T3) were taken during citric acid production; the first of these (T2), while glucose was being consumed and the second (T3) during the main xylose consumption phase after glucose was fully consumed. Differential expression analysis revealed a greater degree of similarity between the two citric acid producing timepoints (T2 and T3) than for comparisons between these and the non-citric acid producing timepoint (T1) (Fig. 2).

To enable us to identify potential in vivo constraints that limit citric acid production, we associated transcripts with the reactions in the metabolic model and determined expression at a reaction-level. The most differentially expressed transcripts with reaction associations are shown in Tables 1, 2, 3. With reaction-level expression determined, we constructed metabolic schematics to 


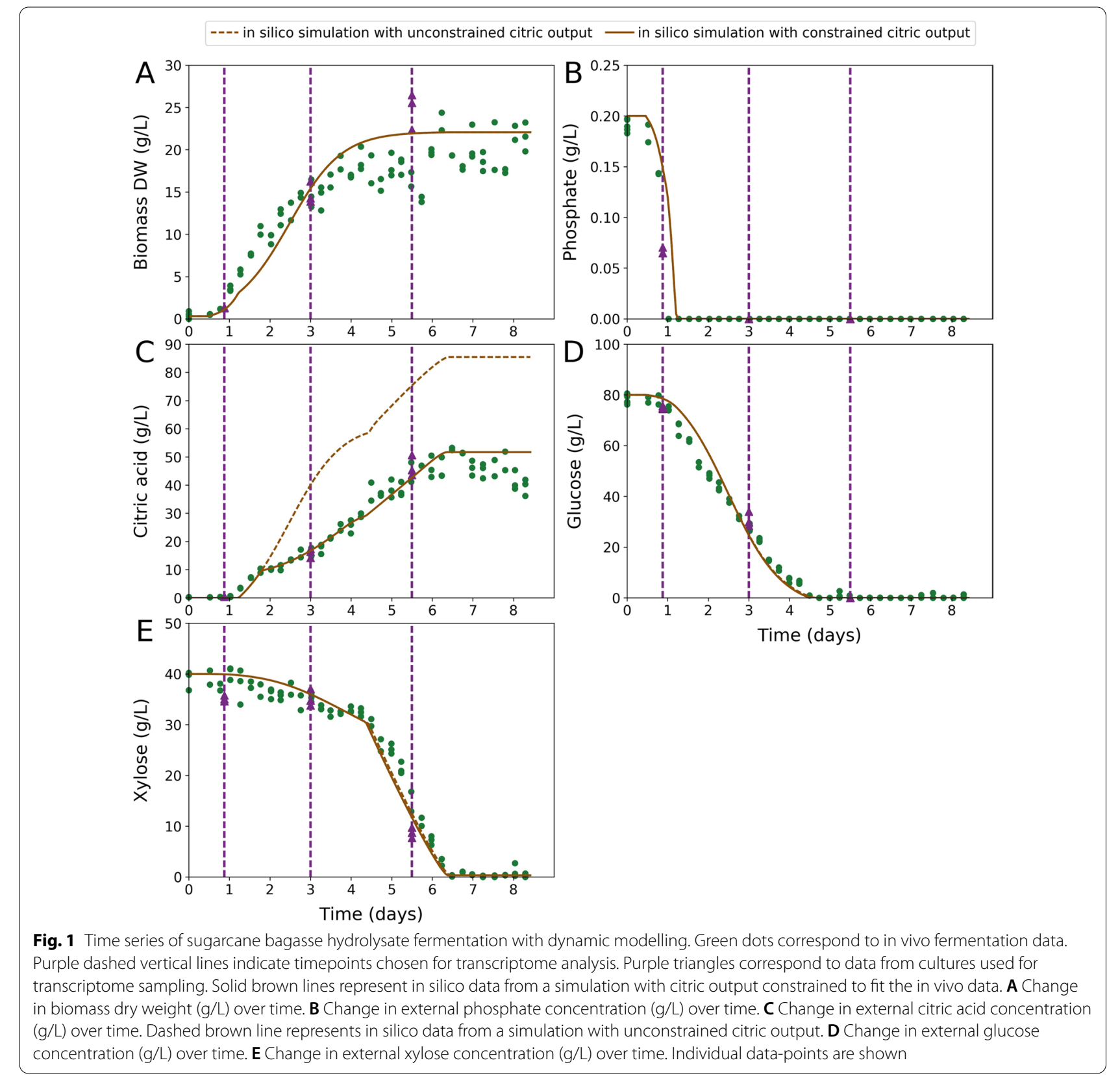

visualise the changes in the transcriptome and their reaction-level effects for a given comparison (Fig. 3).

In comparing $\mathrm{T} 1$ with $\mathrm{T} 2$, the scale of change is clear when transitioning to citric acid production with widespread differential expression events observed across metabolism (Fig. 3A). In particular, reactions involved in biomass production were down-regulated, while citrate export was up-regulated together with the downregulation of TCA cycle reactions involved in citrate catabolism. Unexpectedly, pyruvate carboxylase whose activity is important to citric acid production [18] was down-regulated, suggesting this step as a point of constraint in vivo.

The expression changes are less extensive when transitioning from glucose to xylose consumption and appear to be directed at the change in substrate use (Fig. 3B). These include up-regulation of xylose import and xylulose kinase as well as phosphoketolase and acetate kinase that appear to activate an alternative xylose catabolic pathway, which may be associated with upregulation of the glyoxylate shunt through an increased supply of acetyl-CoA. We also observed further 


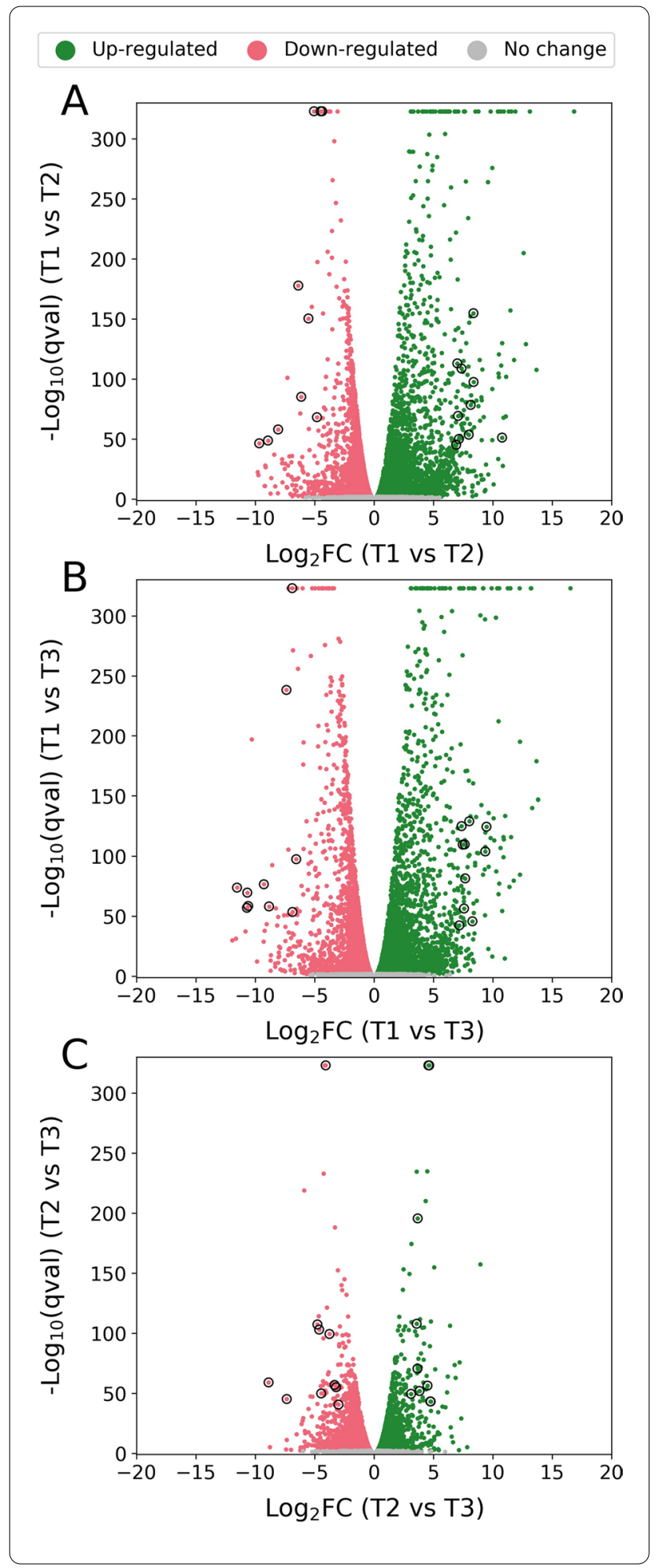

up-regulation of citrate export, yet the rate of citric acid production in silico is around 2.3 times higher at T2 than T3 when citric output is unconstrained (Table 4). The lower citrate exporter expression at T2
Fig. 2 Volcano plots showing the differential expression between selected timepoints. Green dots indicate transcripts that are up-regulated. Red dots indicate transcripts that are down-regulated. Grey dots indicate transcripts that are not significantly differentially expressed. A $q$ value (adjusted $p$ value) threshold of 0.01 was applied to determine statistical significance. The $x$-axis corresponds to log2FC between selected timepoints. The $y$-axis corresponds to $-\log 10$ of the $q$ value (adjusted $p$ value). Data-points corresponding to the most significantly differentially expressed transcripts ( $q$ value $<1 \mathrm{E}-40$ and ranked by $\log 2 \mathrm{FC}$ ) with reaction associations in iDU1327 are circled. A Differential expression analysis between $\mathrm{T} 1$ and $\mathrm{T} 2$. The transcripts and their associated reactions that correspond to circled data-points are given in Table 1. B Differential expression analysis between T1 and T3. The transcripts and their associated reactions that correspond to circled data-points are given in Table 2. C Differential expression analysis between $\mathrm{T} 2$ and T3. The transcripts and their associated reactions that correspond to circled data-points are given in Table 3

with respect to T3 may indicate citrate export as a point of constraint in vivo.

\section{Investigating suboptimal citric acid production by transcriptome-guided in silico evolution}

To develop a metabolic understanding of suboptimal citric acid production, we developed an evolutionary algorithm to perform in silico evolution of the model with the aim of reflecting non-optimised strains. We focused on $\mathrm{T} 2$ as citric output is around 2.6 times higher at T2 when unconstrained (Table 4) than when constrained (Table 5) to fit in vivo data, whereas citric output at T3 is virtually the same. The objective was to identify changes to flux bounds that constrain citric output to the value that closely fits in vivo data while maintaining the same carbon input and biomass output. To achieve this, we adapted an evolutionary algorithm [19] to evolve the model to more accurately reflect the in vivo metabolic state that is associated with constrained citric production. As many solutions may exist to this, we used the transcriptomic data to guide the in silico evolution to limit solutions to those that are more likely to resemble the one indicated by the transcriptome. This constrained the evolutionary algorithm to alter flux bounds only on reactions where there is a significant differential expression, with such cases implying transcriptional regulation over the reaction's activity. We compared and analysed the solutions from eight independent runs of the evolutionary algorithm to suggest targets for increasing citric acid productivity (Fig. 4). In total, we found 91 reactions suggested for targeted intervention of their activity; 65 for down-regulation and 26 for up-regulation (Table 6). Together, the list of targets provides high coverage of all potential targets that could bring about optimal citric acid production. Some of the targets were expected and consistent with the literature for example the 
Table 1 Most significantly differentially expressed transcripts between timepoints T1 and T2 with reaction associations in iDU1327

\begin{tabular}{|c|c|c|c|c|}
\hline Transcript ID & Effect & $\log 2 \mathrm{FC}$ & Associated reactions in iDU1327 & Names of associated reactions \\
\hline Aspni_transcript.chr_202G213.1 & Down-regulated & -9.7 & R462; R463; N1; R464 & Catalase \\
\hline Aspni_transcript.chr_202G683.1 & Down-regulated & -8.9 & R623 & $\begin{array}{l}\text { 5-Oxo-L-proline amidohydrolase (ATP- } \\
\text { hydrolysing) }\end{array}$ \\
\hline Aspni_transcript.chr_401G28.1 & Down-regulated & -8.1 & R258; R259 & Glucose oxidase \\
\hline Aspni_transcript.chr_701G586.1 & Down-regulated & -6.4 & R1227 & Sulphite reductase \\
\hline Aspni_transcript.chr_202G195.1 & Down-regulated & -6.1 & R462; R463; N1; R464 & Catalase \\
\hline Aspni_transcript.chr_101G17.1 & Down-regulated & -5.5 & R332; R333; R334 & Alpha-galactosidase \\
\hline Aspni_transcript.chr_304G54.1 & Down-regulated & -5 & R74; R511 & $\begin{array}{l}\text { Formate oxidase; Phosphoglycerate dehy- } \\
\text { drogenase }\end{array}$ \\
\hline Aspni_transcript.chr_302G484.1 & Down-regulated & -4.8 & R305; R335; NR2 & $\begin{array}{l}\text { Fructan beta-fructosidase; Invertase; } \\
\text { Stachyose fructohydrolase }\end{array}$ \\
\hline Aspni_transcript.chr_301G287.1 & Down-regulated & -4.5 & R477; R485; R1246 & $\begin{array}{l}\text { Argininosuccinate synthase; } \\
\text { L-alanine:tRNA(Ala) ligase }\end{array}$ \\
\hline Aspni_transcript.chr_101G512.1 & Down-regulated & -4.4 & R417; R418 & Chitinase \\
\hline Aspni_transcript.chr_604G19.1 & Up-regulated & 10.8 & R89; R90; R95; R96; R97; R98 & $\begin{array}{l}\text { Propanoate:CoA ligase (AMP-forming); } \\
\text { Propionyl-CoA synthetase }\end{array}$ \\
\hline Aspni_transcript.chr_402G104.3 & Up-regulated & 8.4 & R377 & Salicylate hydroxylase \\
\hline Aspni_transcript.chr_202G947.1 & Up-regulated & 8.4 & R35 & Citrate synthase \\
\hline Aspni_transcript.chr_601G472.1 & Up-regulated & 8.1 & R398 & 4-Carboxymuconolactone decarboxylase \\
\hline Aspni_transcript.chr_604G21.1 & Up-regulated & 8 & R124; R131 & $\begin{array}{l}\text { Dihydrofolate synthase; Tetrahydrofolylpo- } \\
\text { lyglutamate synthase }\end{array}$ \\
\hline Aspni_transcript.chr_601G138.1 & Up-regulated & 7.4 & R490 & Acetylglutamate kinase \\
\hline Aspni_transcript.chr_601G143.1 & Up-regulated & 7.2 & R1187 & $\begin{array}{l}\text { Trans, trans-farnesyl- } \\
\text { diphosphate:isopentenyl-diphosphate } \\
\text { farnesyltranstransferase }\end{array}$ \\
\hline Aspni_transcript.chr_402G104.6 & Up-regulated & 7.1 & R377 & Salicylate hydroxylase \\
\hline Aspni_transcript.chr_503G231.2 & Up-regulated & 7 & R411 & Glucosamine-6-phosphate deaminase \\
\hline Aspni_transcript.chr_603G120.1 & Up-regulated & 6.9 & $\begin{array}{l}\text { R791; R796; R801; R806; R811; R816; R821; } \\
\text { R826; R831; R837; R842; R847; R852; R857; } \\
\text { R862; R867; R872 }\end{array}$ & 3-Oxoacyl-[acyl-carrier-protein] reductase \\
\hline
\end{tabular}

Transcripts shown have $q$ value $<1 \mathrm{E}-40$ and are ranked by log $2 \mathrm{FC}$

up-regulation of citrate export and pyruvate carboxylase, while other targets were novel such as the down-regulation of inorganic diphosphatase.

\section{Discussion}

In our in vivo fermentation experiments with sugarcane bagasse hydrolysate, we observed a promising yield of citric acid; up to $50 \mathrm{~g} / \mathrm{L}$ in 6 days from $80 \mathrm{~g} / \mathrm{L}$ glucose and $40 \mathrm{~g} / \mathrm{L}$ xylose. In our simulations, however, up to $85 \mathrm{~g} / \mathrm{L}$ citric acid could be produced. By our analysis of the transcriptome at key timepoints and with our in silico toolkit, we have determined what may underlie the suboptimal citric acid production. The exhaustive list of targets all involve a common feature: an aim to minimise carbon loss as $\mathrm{CO}_{2}$ and maximise citric output.

One example of a target that is associated with minimising carbon loss via $\mathrm{CO}_{2}$ is the down-regulation of inorganic diphosphatase. Forcing flux of this reaction alone was able to decrease citric output to the target value, suggesting that a high level of inorganic diphosphatase activity may negatively affect citric acid production. The reaction catalysed by inorganic diphosphatase acts to dissipate energy, thereby supporting a high carbon input flux with carbon output predominantly to $\mathrm{CO}_{2}$. This finding also relates to our previous work [17] on the relationship between phosphate levels and citric acid production. Decreased activity of inorganic diphosphatase may limit internal phosphate levels and enhance citric acid production. The majority of our targets for down-regulation are associated with anabolic pathways involved in the synthesis of biomass components. As the production of biomass becomes restricted by phosphate availability during citric acid production, any excess in anabolic flux would result in futile pathways. Comparison of the biomass output flux values between $\mathrm{T} 2$ and $\mathrm{T} 3$ reveals that the growth rate is $\approx 30$-fold higher at $\mathrm{T} 2$, yet the fold changes in expression of anabolic reactions are significantly less than the fold change in growth rate, suggesting that the expression of these reactions is not excessive at $\mathrm{T} 2$. 
Table 2 Most significantly differentially expressed transcripts between timepoints T1 and T3 with reaction associations in iDU1327

\begin{tabular}{|c|c|c|c|c|}
\hline Transcript ID & Effect & Log $2 F C$ & Associated reactions in iDU1327 & Names of associated reactions \\
\hline Aspni_transcript.chr_601G340.1 & Down-regulated & -11.5 & R544; R554 & Dihydroxy acid dehydratase \\
\hline Aspni_transcript.chr_202G213.1 & Down-regulated & -10.7 & $\mathrm{R} 462 ; \mathrm{R} 463 ; \mathrm{N1} ; \mathrm{R} 464$ & Catalase \\
\hline Aspni_transcript.chr_202G683.1 & Down-regulated & -10.7 & $\mathrm{R} 623$ & $\begin{array}{l}\text { 5-Oxo-L-proline amidohydrolase (ATP- } \\
\text { hydrolysing) }\end{array}$ \\
\hline Aspni_transcript.chr_102G681.1 & Down-regulated & -10.6 & $\mathrm{R} 462 ; \mathrm{R} 463 ; \mathrm{N1} ; \mathrm{R} 464$ & Catalase \\
\hline Aspni_transcript.chr_401G28.1 & Down-regulated & -9.3 & $\mathrm{R} 258 ; \mathrm{R} 259$ & Glucose oxidase \\
\hline Aspni_transcript.chr_801G200.1 & Down-regulated & -8.8 & $\begin{array}{l}\text { R790; R795; R800; R805; R810; R815; R820; } \\
\text { R825; R830; R836; R841; R846; R851; R856; } \\
\text { R861; R866; R871 }\end{array}$ & 3-Oxoacyl-[acyl-carrier-protein] synthase \\
\hline Aspni_transcript.chr_701G586.1 & Down-regulated & -7.4 & $\mathrm{R} 1227$ & Sulphite reductase \\
\hline Aspni_transcript.chr_603G16.1 & Down-regulated & -6.9 & R451 & ATP synthase \\
\hline Aspni_transcript.chr_302G588.1 & Down-regulated & -6.9 & R719 & Uracil phosphoribosyltransferase \\
\hline Aspni_transcript.chr_202G195.1 & Down-regulated & -6.5 & $\mathrm{R} 462 ; \mathrm{R} 463 ; \mathrm{N} 1 ; \mathrm{R} 464$ & Catalase \\
\hline Aspni_transcript.chr_402G104.3 & Up-regulated & 9.5 & R377 & Salicylate hydroxylase \\
\hline Aspni_transcript.chr_601G472.1 & Up-regulated & 9.4 & R398 & 4-Carboxymuconolactone decarboxylase \\
\hline Aspni_transcript.chr_202G1357.1 & Up-regulated & 8.3 & $\begin{array}{l}\text { R362; R618; R619; R785; R1244; NR28; } \\
\text { NR37 }\end{array}$ & $\begin{array}{l}\text { Benzonitrilase; Nitrilase; Formamide hydro- } \\
\text { lyase; Phenylacetonitrile aminohydrolase }\end{array}$ \\
\hline Aspni_transcript.chr_601G138.1 & Up-regulated & 8 & R490 & Acetylglutamate kinase \\
\hline Aspni_transcript.chr_402G104.6 & Up-regulated & 7.7 & R377 & Salicylate hydroxylase \\
\hline Aspni_transcript.chr_601G80.1 & Up-regulated & 7.6 & R65; R66 & Oxalate decarboxylase \\
\hline Aspni_transcript.chr_601G143.1 & Up-regulated & 7.6 & R1187 & $\begin{array}{l}\text { Trans,trans-farnesyl- } \\
\text { diphosphate:isopentenyl-diphosphate } \\
\text { farnesyltranstransferase }\end{array}$ \\
\hline Aspni_transcript.chr_401G532.1 & Up-regulated & 7.5 & R378; R402; R404; R615; NR23 & Amine oxidase \\
\hline Aspni_transcript.chr_503G231.2 & Up-regulated & 7.4 & R411 & Glucosamine-6-phosphate deaminase \\
\hline Aspni_transcript.chr_304G666.1 & Up-regulated & 7.2 & $\mathrm{R} 211 ; \mathrm{R} 1115$ & $\begin{array}{l}\text { Glycerol 3-phosphate dehydrogenase } \\
\text { (NAD + dependent) }\end{array}$ \\
\hline
\end{tabular}

Transcripts shown have $q$ value $<1 \mathrm{E}-40$ and are ranked by $\log 2 \mathrm{FC}$

Among our targets are expected changes in metabolism including the up-regulation of citrate export and pyruvate carboxylase, both of which have significantly lower expression at $\mathrm{T} 2$ with respect to $\mathrm{T} 3$. The flux through these steps would be higher at T2 than T3 in the case of optimal citric acid production, suggesting that expression should also be higher at $\mathrm{T} 2$ contrary to what we see in this study. The citrate exporter has been overexpressed previously which resulted in a fivefold increase in citric acid production [20], and pyruvate carboxylase has been overexpressed for increasing production of malic acid [21].

The importance of energy metabolism to citric acid production is highlighted by the frequent targeting of oxidative phosphorylation reactions. These reactions were down-regulated from $\mathrm{T} 1$ to $\mathrm{T} 2$ by around 2-2.6fold, and constraining the flux of these reactions in line with the transcriptome data led to a drop in citric production. This may seem counter-intuitive as the addition of oxidative phosphorylation inhibitors has been shown to increase citric acid production; however, negative effects were observed when the activity of oxidative phosphorylation was too low [22]. This is consistent with our study, which shows that over-constraint of oxidative phosphorylation decreases citric output.

The objective of our study was to identify targets for increasing citric acid production by integrating transcriptome data with metabolic modelling. Many efforts have been made to integrate transcriptome data with metabolic models, with early examples including the GIMME algorithm [10], E-Flux [11], and iMAT [13], and more recently SPOT [15]. A disadvantage of these approaches was their use of absolute expression data that may not correlate closely with reaction activity. An alternative is to use differential expression data that indicate which reactions are subject to transcriptional regulation, such as MADE where differential expression data are used to determine binary expression states [14]. Other methods include PROM that requires a regulatory network [12] and LBFBA that relies on flux data to parameterise linear reaction-specific functions to determine flux bounds from expression data [16]. Our approach infers from differential expression data the metabolic factors that underpin suboptimal citric acid production in 
Table 3 Most significantly differentially expressed transcripts between timepoints T2 and T3 with reaction associations in iDU1327

\begin{tabular}{|c|c|c|c|c|}
\hline Transcript ID & Effect & $\log 2 \mathrm{FC}$ & Associated reactions in iDU1327 & Names of associated reactions \\
\hline Aspni_transcript.chr_302G588.1 & Down-regulated & -8.9 & R719 & Uracil phosphoribosyltransferase \\
\hline Aspni_transcript.chr_302G590.1 & Down-regulated & -7.3 & R173 & $\begin{array}{l}\text { GTP 7,8-8,9-dihydrolase (diphosphate- } \\
\text { forming) }\end{array}$ \\
\hline Aspni_transcript.chr_401G344.1 & Down-regulated & -4.8 & R1176 & $\begin{array}{l}\text { 3-Hydroxy-3-methylglutaryl coenzyme A } \\
\text { synthase }\end{array}$ \\
\hline Aspni_transcript.chr_202G1142.1 & Down-regulated & -4.6 & R193; R198 & Alcohol dehydrogenase \\
\hline Aspni_transcript.chr_802G171.1 & Down-regulated & -4.4 & $\begin{array}{l}\text { R228; R230; R791; R796; R801; R806; R811; } \\
\text { R816; R821; R826; R831; R837; R842; R847; } \\
\text { R852; R857; R862; R867; R872 }\end{array}$ & $\begin{array}{l}\text { L-Xylulose reductase;3-Oxoacyl-[acyl- } \\
\text { carrier-protein] reductase }\end{array}$ \\
\hline Aspni_transcript.chr_603G16.1 & Down-regulated & -4.1 & R451 & ATP synthase \\
\hline Aspni_transcript.chr_102G146.1 & Down-regulated & -3.7 & $\begin{array}{l}\text { R791; R796; R801; R806; R811; R816; R821; } \\
\text { R826; R831; R837; R842; R847; R852; R857; } \\
\text { R862; R867; R872 }\end{array}$ & 3-Oxoacyl-[acyl-carrier-protein] reductase \\
\hline Aspni_transcript.chr_101G224.1 & Down-regulated & -3.3 & R322 & alpha-amylase \\
\hline Aspni_transcript.chr_304G378.1 & Down-regulated & -3.2 & $\begin{array}{l}\text { R791; R796; R801; R806; R811; R816; R821; } \\
\text { R826; R831; R837; R842; R847; R852; R857; } \\
\text { R862; R867; R872 }\end{array}$ & 3-Oxoacyl-[acyl-carrier-protein] reductase \\
\hline Aspni_transcript.chr_801G344.1 & Down-regulated & -3 & R182; R188; R265; R1207; NR14; NR26 & $\begin{array}{l}\text { Riboflavin-5-phosphate phosphohydrolase; } \\
\text { Thiamin monophosphate phosphohydro- } \\
\text { lase; Phosphatidate phosphatase; 4-Nitro- } \\
\text { phenyl phosphate phosphohydrolase; } \\
\text { Glycerone phosphate phosphohydrolase }\end{array}$ \\
\hline Aspni_transcript.chr_304G666.1 & Up-regulated & 4.8 & R211; R1115 & $\begin{array}{l}\text { Glycerol 3-phosphate dehydrogenase } \\
\text { (NAD + dependent) }\end{array}$ \\
\hline Aspni_transcript.chr_101G504.1 & Up-regulated & 4.7 & $\mathrm{R} 71 ; \mathrm{R} 75 ; \mathrm{R} 516$ & $\begin{array}{l}\text { S-(hydroxymethyl)glutathione dehydro- } \\
\text { genase; Formaldehyde dehydrogenase; } \\
\text { Threonine dehydrogenase }\end{array}$ \\
\hline Aspni_transcript.chr_602G271.2 & Up-regulated & 4.7 & R107; R108 & Succinate-semialdehyde dehydrogenase \\
\hline Aspni_transcript.chr_501G182.1 & Up-regulated & 4.6 & R106; R611 & 4-Aminobutyrate transaminase \\
\hline Aspni_transcript.chr_102G293.1 & Up-regulated & 4.5 & R107; R108 & Succinate-semialdehyde dehydrogenase \\
\hline Aspni_transcript.chr_202G964.1 & Up-regulated & 3.8 & R153; R479; R604 & $\begin{array}{l}\text { Adenosyl:methionine-8-amino-7-oxon- } \\
\text { onanoate aminotransferase; Ornithine } \\
\text { transaminase }\end{array}$ \\
\hline Aspni_transcript.chr_101G108.1 & Up-regulated & 3.7 & R378; R402; R404; R615; NR23 & Amine oxidase \\
\hline Aspni_transcript.chr_402G585.2 & Up-regulated & 3.7 & R33; R34 & Phosphoketolase \\
\hline Aspni_transcript.chr_202G803.1 & Up-regulated & 3.6 & R103; R104 & $\begin{array}{l}\text { Methylmalonate-semialdehyde dehydro- } \\
\text { genase }\end{array}$ \\
\hline Aspni_transcript.chr_402G613.1 & Up-regulated & 3.1 & R78 & Pyruvate decarboxylase \\
\hline
\end{tabular}

Transcripts shown have $q$ value $<1 \mathrm{E}-40$ and are ranked by log $2 \mathrm{FC}$

Aspergillus, and is tailored to applications where there is a defined metabolic goal. Its basis is an evolutionary algorithm with changes to flux bounds guided by differential expression data. Its limitation is that it outputs a set of possible solutions rather than a unique solution.

\section{Conclusions}

In this study, we demonstrate the production of citric acid from lignocellulosic hydrolysate by an engineered variant of $A$. niger ATCC1015. By performing in silico simulations using a dynamic model, we show how transcriptomic data across multiple timepoints can be coupled with evolutionary and metabolic modelling to inform targeted engineering strategies aimed at maximising productivity from a chosen feedstock. The same in silico strategies employed here can be applied to other biotechnological goals, assisting efforts to harness the potential of microorganisms for bio-based production of valuable chemicals.

\section{Methods}

Preparation of sugarcane bagasse hydrolysate

Sugarcane bagasse was obtained from Natems Sugar Pvt. Ltd. (India) and dried at $50{ }^{\circ} \mathrm{C}$ overnight to reach constant weight. Bagasse was milled using a knife mill with a $1 \mathrm{~mm}$ sieve prior to pre-treatment. Pre-treatment was 


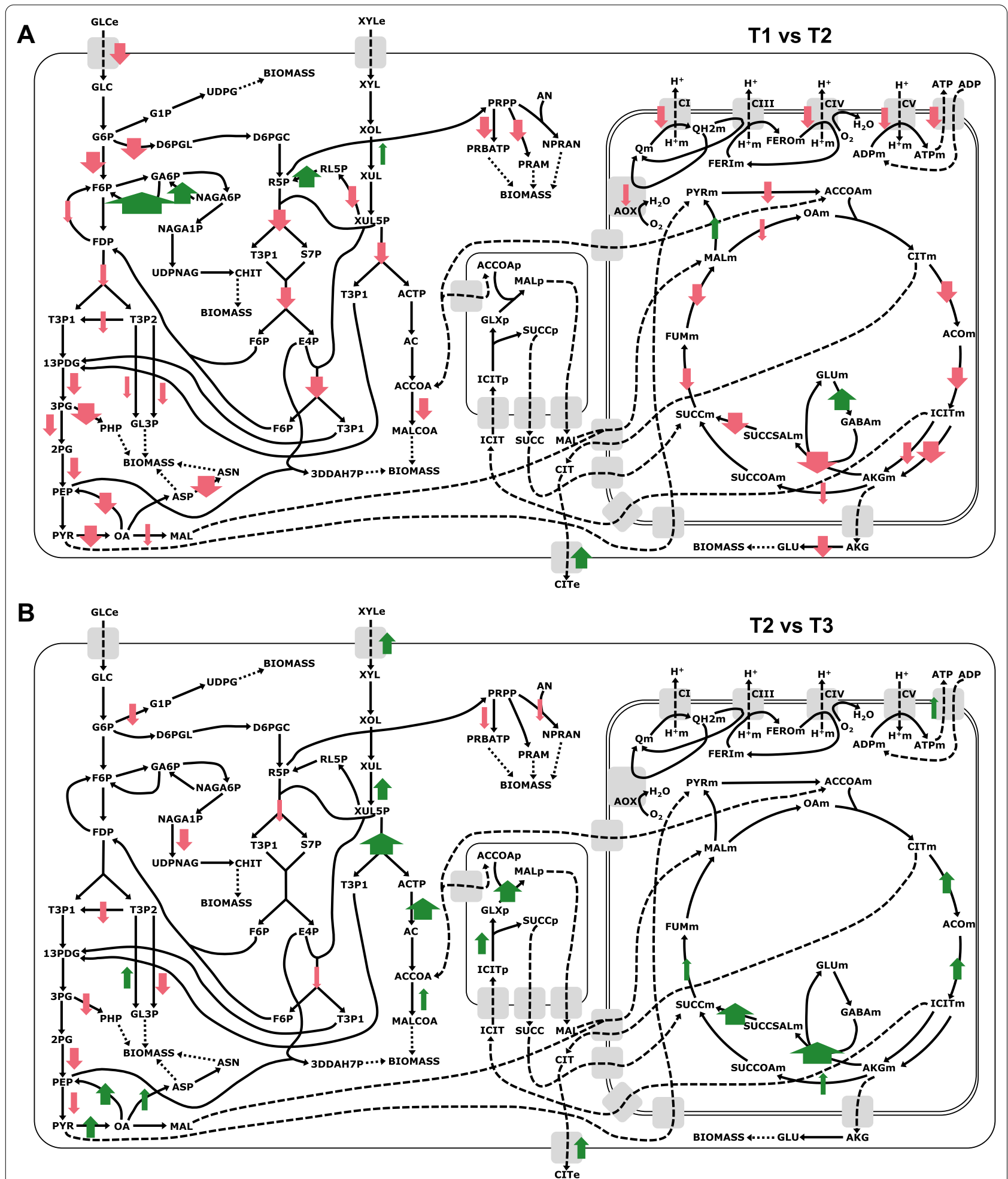

Fig. 3 Metabolic schematics showing the key changes in the transcriptome from T1 to T2 (A) and from T2 to T3 (B) and their reaction-level effects. Green upward and red downward arrows indicate significantly up- and down-regulated reactions, respectively ( $q$ value $<0.01$ and log2FC $>0.7)$. The arrow width is directly proportional to the log2FC value. The full names of abbreviated metabolites are given in the iDU1327 model (see Additional file 1). Reactions included are shown in simplified form with only key reactants and products 
Table 4 Input/output fluxes in iDU1327 at selected timepoints without constraint on citric output

\begin{tabular}{|c|c|c|c|}
\hline Input/output reaction & T1 flux (mmol gDW ${ }^{-1} h^{-1}$ ) & T2 flux ( $\left.\mathrm{mmol} \mathrm{gDW}^{-1} \mathrm{~h}^{-1}\right)$ & $\begin{array}{l}\text { T3 flux (mmol } \\
\left.\text { gDW }^{-1} h^{-1}\right)\end{array}$ \\
\hline Glucose (DGLCe <==>) & -1.2552 & -0.4392 & 0.0 \\
\hline Xylose $(X Y L e<==>)$ & -0.0718 & -0.0647 & -0.1936 \\
\hline External phosphate $(\mathrm{Ple}<==>)$ & -0.1455 & 0.0 & 0.0 \\
\hline Internal phosphate $(\mathrm{Pl}<==>)$ & 0.1339 & -0.0019 & -0.00005 \\
\hline Biomass & $0.1207\left(h^{-1}\right)$ & $0.0195\left(h^{-1}\right)$ & $0.0006\left(h^{-1}\right)$ \\
\hline Citric acid (CIT-e $<==>$ ) & 0.0 & 0.3159 & 0.135 \\
\hline Carbon dioxide $\left(\mathrm{CO}_{2} \mathrm{e}<==>\right)$ & 3.3671 & 0.3311 & 0.137 \\
\hline Oxygen $\left(\mathrm{O}_{2} \mathrm{e}<==>\right)$ & -1.9835 & -0.581 & -0.3331 \\
\hline
\end{tabular}

Table 5 Input/output fluxes in iDU1327 at selected timepoints with citric output constrained in line with in vivo data

\begin{tabular}{|c|c|c|c|}
\hline Input/output reaction & T1 flux (mmol gDW $\left.{ }^{-1} \mathrm{~h}^{-1}\right)$ & T2 flux (mmol gDW $\left.{ }^{-1} \mathrm{~h}^{-1}\right)$ & $\begin{array}{l}\text { T3 flux } \\
\left(\mathrm{mmol} \mathrm{gDW}^{-1} \mathrm{~h}^{-1}\right)\end{array}$ \\
\hline Glucose (DGLCe <==>) & -1.2552 & -0.4392 & 0.0 \\
\hline Xylose (XYLe $<==>$ ) & -0.0718 & -0.0647 & -0.1936 \\
\hline External phosphate $(\mathrm{Ple}<==>$ ) & -0.1455 & 0.0 & 0.0 \\
\hline Internal phosphate $(\mathrm{Pl}<==>)$ & 0.1339 & -0.0019 & -0.00005 \\
\hline Biomass & $0.1207\left(h^{-1}\right)$ & $0.0195\left(h^{-1}\right)$ & $0.0006\left(h^{-1}\right)$ \\
\hline Citric acid (CIT-e $<==>$ ) & 0.0 & 0.12 & 0.12 \\
\hline Carbon dioxide $\left(\mathrm{CO}_{2} \mathrm{e}<==>\right)$ & 3.3671 & 1.5066 & 0.2268 \\
\hline Oxygen $\left(\mathrm{O}_{2} \mathrm{e}<==>\right)$ & -1.9835 & -1.4626 & -0.4004 \\
\hline
\end{tabular}

performed in a $2 \mathrm{~L}$ vessel (Parr Instrument Company, Moline, IL, US): $100 \mathrm{~g}$ milled bagasse was added to the vessel and mixed with $900 \mathrm{~mL} 0.4 \mathrm{M} \mathrm{NaOH}$ to homogeneity. The vessel was heated to $140{ }^{\circ} \mathrm{C}$ and maintained at $140{ }^{\circ} \mathrm{C}$ for $45 \mathrm{~min}$, and then cooled on ice until the temperature dropped to $60{ }^{\circ} \mathrm{C}$. The contents of the vessel were transferred to a fruit press after pre-treatment. Pre-treated bagasse was pressed to remove the pretreatment liquor and rinsed twice in $500 \mathrm{~mL}$ acidified $\mathrm{dH}_{2} \mathrm{O}$. The acidified $\mathrm{dH}_{2} \mathrm{O}$ was prepared by adding $100 \mu \mathrm{l}$ concentrated $\mathrm{H}_{2} \mathrm{SO}_{4}$ to $1.2 \mathrm{~L} \mathrm{dH_{2 }} \mathrm{O}$. After rinsing, pretreated bagasse was adjusted to $\mathrm{pH} 5-6$ by the addition of concentrated $\mathrm{H}_{2} \mathrm{SO}_{4}$. The pre-treated bagasse was then transferred to Weck jars and autoclaved $\left(121^{\circ} \mathrm{C} 15 \mathrm{~min}\right)$ followed by storage at $4{ }^{\circ} \mathrm{C}$ until use. The pre-treated bagasse was subjected to enzymatic hydrolysis in $1 \mathrm{~L}$ shake flasks: Pre-treated bagasse was added to the flask at the equivalent of $50 \mathrm{~g}$ dry weight and autoclaved. Under aseptic conditions, $10 \mathrm{~mL} 1 \mathrm{M}$ MES buffer pH 5.5 (filter sterile) and $24.5 \mathrm{~mL}$ enzyme solution (filter sterile) were added, followed by sterile $\mathrm{dH}_{2} \mathrm{O}$ up to a final volume of $400 \mathrm{~mL}$. Enzyme solution was prepared by mixing $20 \mathrm{~g}$ Cellic CTec3 (Novozymes) with 20 g 25 mM MES buffer $\mathrm{pH}$ 5.5. Flasks were incubated at $50{ }^{\circ} \mathrm{C}$ with shaking at $160 \mathrm{rpm}$ for $48 \mathrm{~h}$. After hydrolysis, the hydrolysate slurry was centrifuged at $4600 \mathrm{rpm}$ for $20 \mathrm{~min}$ in a Multifuge
3 SR benchtop centrifuge (Heraeus, Germany). The clear supernatant was filtered through Whatman glass microfibre filters GF/F (GE Healthcare UK Ltd., UK) using a vacuum pump and then filter sterilised into a sterile glass bottle using a Stericap ${ }^{\mathrm{TM}}$ PLUS filter (Merck Millipore). The filter sterile hydrolysate was stored at $4{ }^{\circ} \mathrm{C}$.

\section{Shake flask fermentation experiments with time-course sampling}

Fermentation experiments were performed in $250 \mathrm{~mL}$ baffled shake flasks (Bellco Glass Inc.; Vineland, NJ, USA) at a working volume of $30 \mathrm{~mL}$. Bagasse hydrolysate was supplemented with $3 \mathrm{~g} / \mathrm{L} \mathrm{NaNO}_{3}$ and $10 \mathrm{mM}$ uridine. Spores from the A. niger strain ATCC1015 $\triangle p y r G \Delta o a h$ $\Delta$ gox [17] were added at $1 \times 10^{6}$ spores $/ \mathrm{mL}$. Spores were harvested from potato dextrose agar slants supplemented with $10 \mathrm{mM}$ uridine. The slants were incubated at $37{ }^{\circ} \mathrm{C}$ for 3 days and spores were harvested using sterile cotton wool buds. Spores were suspended in saline Tween $(0.1 \%$ Tween $80,9 \mathrm{~g} / \mathrm{L} \mathrm{NaCl}$ ) and centrifuged at $2500 \mathrm{rpm}$ for $5 \mathrm{~min}$. Spores were then washed 3 times in saline Tween prior to being used to inoculate cultures. Cultures were incubated at $30{ }^{\circ} \mathrm{C}$ with shaking at $250 \mathrm{rpm}$ for 8 days. $500 \mu \mathrm{l}$ homogeneous samples were taken twice daily $6 \mathrm{~h}$ apart. The supernatant and the biomass were separated by centrifugation at $20238 \mathrm{~g}$ for $3 \mathrm{~min}$ and stored 


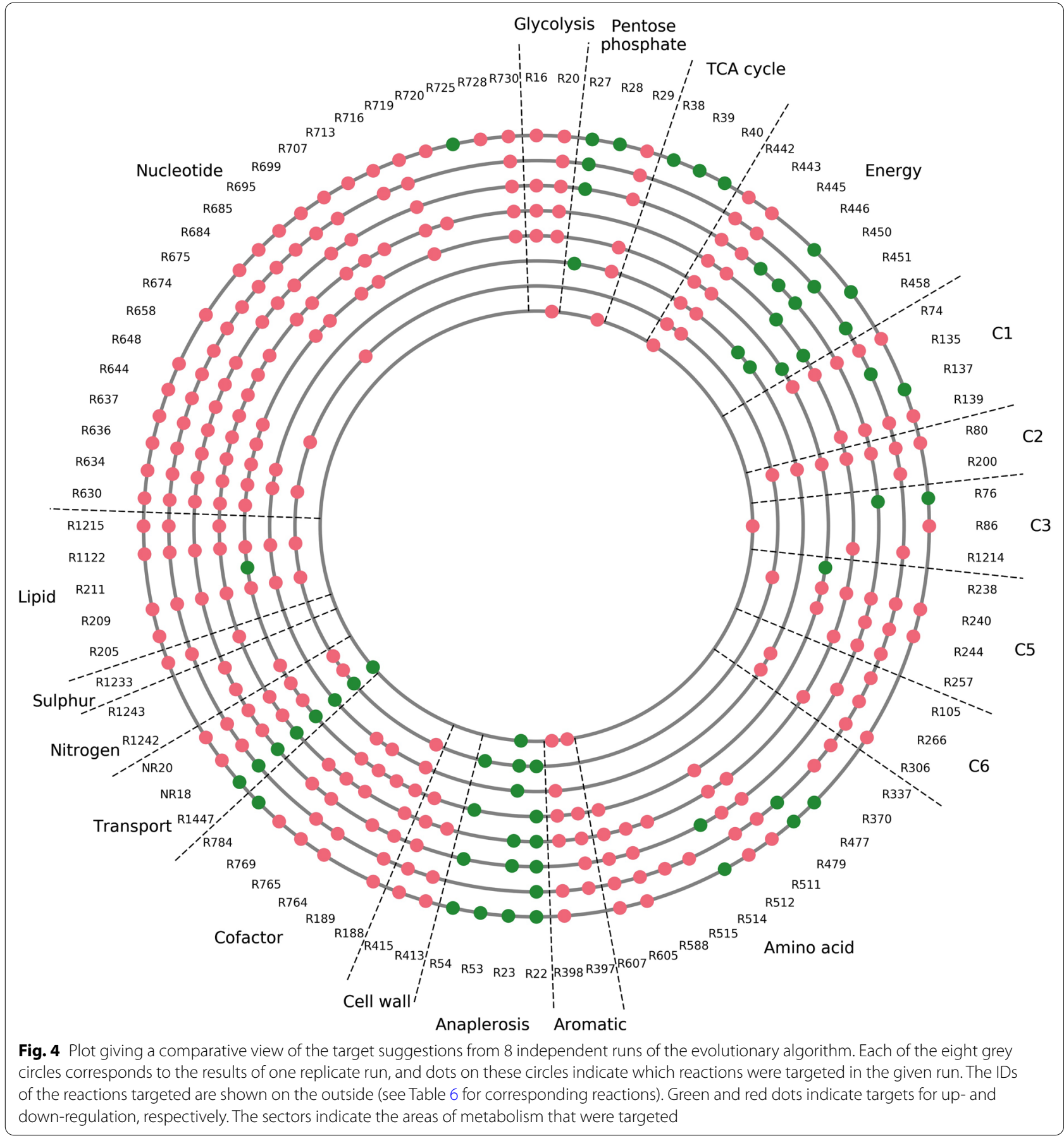

at $-20{ }^{\circ} \mathrm{C}$ to prevent any changes to metabolite concentrations in the supernatant and any changes to biomass dry weight.

\section{Extracellular metabolite and biomass dry weight analysis} Glucose, xylose, and citric acid were determined enzymatically using the K-GLUC, K-XYLOSE, and K-CITR kits, respectively (Megazyme International Ireland Ltd., Wicklow, Ireland). Phosphate was determined using an assay kit (ab65622; Abcam, Cambridge, UK). Biomass dry weight was determined by washing biomass samples in pre-dried, pre-weighed $1.5 \mathrm{~mL}$ Eppen-

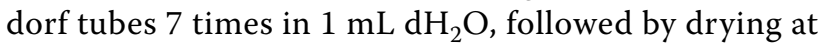
$70{ }^{\circ} \mathrm{C}$ to constant weight. Between each of the washing steps, the biomass samples were centrifuged at $20238 \mathrm{~g}$ 
Table 6 Suggested targets for increasing citric acid output based on results from the evolutionary algorithm (primarily ranked by frequency and then by citric \%increase)

\begin{tabular}{|c|c|c|c|c|c|}
\hline Reaction ID ${ }^{\mathrm{a}}$ & Name & Equation & Target & Frequency $^{\mathbf{b}}$ & $\begin{array}{l}\text { Citric } \\
\text { \%increase }\end{array}$ \\
\hline R1447 & Citrate exporter & $\mathrm{CIT}-\mathrm{e} \leftrightarrow \mathrm{CIT}$ & Up-regulate & 8 & 163 \\
\hline R442 & Diphosphatase & $\mathrm{PPI}+\mathrm{H}_{2} \mathrm{O} \rightarrow 2^{*} \mathrm{PI}+\mathrm{H}$ & Down-regulate & 8 & 163 \\
\hline R209 & $\begin{array}{l}\text { Glycerol 3-phosphate dehydrogenase (FAD } \\
\text { dependent) }\end{array}$ & $\mathrm{GL} 3 \mathrm{P}+\mathrm{FADm} \rightarrow \mathrm{T} 3 \mathrm{P} 2+\mathrm{FADH} 2 \mathrm{~m}$ & Down-regulate & 7 & 170 \\
\hline R634 & $\begin{array}{l}\text { Phosphoribosyl amino imidazolesuccino- } \\
\text { carbozamide synthetase }\end{array}$ & $\begin{array}{l}\mathrm{ASP}+\mathrm{ATP}+\mathrm{CAIR} \leftrightarrow 2^{*} \mathrm{H}+\mathrm{PI}+\mathrm{ADP}+\mathrm{SAI}- \\
\mathrm{CAR}\end{array}$ & Down-regulate & 7 & 163 \\
\hline R80 & Acetate kinase & $\mathrm{ATP}+\mathrm{AC} \leftrightarrow \mathrm{ADP}+\mathrm{ACTP}$ & Down-regulate & 7 & 163 \\
\hline R188 & $\begin{array}{l}\text { Thiamin monophosphate phosphohy- } \\
\text { drolase }\end{array}$ & $\mathrm{THMP}+\mathrm{H}_{2} \mathrm{O} \rightarrow \mathrm{THM}+\mathrm{PI}$ & Down-regulate & 7 & 163 \\
\hline R443 & Diphosphatase & $\mathrm{PPIm}+\mathrm{H}_{2} \mathrm{O} \rightarrow 2^{*} \mathrm{PIm}+\mathrm{Hm}$ & Down-regulate & 7 & 163 \\
\hline R1122 & ATP:ethanolamine O-phosphotransferase & $\mathrm{ATP}+\mathrm{ETHLA} \rightarrow \mathrm{ADP}+\mathrm{PEA}+\mathrm{H}$ & Down-regulate & 7 & 163 \\
\hline R22 & Pyruvate carboxylase & $\begin{array}{l}\mathrm{ATP}+\mathrm{PYR}+\mathrm{H}_{2} \mathrm{O}+\mathrm{CO}_{2} \rightarrow \mathrm{ADP}+\mathrm{PI}+\mathrm{OA} \\
+2^{*} \mathrm{H}\end{array}$ & Up-regulate & 6 & 171 \\
\hline R636 & IMP cyclohydrolase & $\mathrm{AICAR}+\mathrm{FTHF} \leftrightarrow \mathrm{THF}+\mathrm{PRFICA}$ & Down-regulate & 6 & 169 \\
\hline R398 & 4-Carboxymuconolactone decarboxylase & $4 \mathrm{CMUCL}+2^{*} \mathrm{H} \rightarrow \mathrm{OAEL}+\mathrm{CO}_{2}$ & Down-regulate & 6 & 163 \\
\hline R20 & Phosphopyruvate hydratase & $2 \mathrm{PG} \leftrightarrow \mathrm{PEP}+\mathrm{H}_{2} \mathrm{O}$ & Down-regulate & 6 & 163 \\
\hline NR18 & Acetyl-CoA:carnitine O-acetyltransferase & $\mathrm{ACCOAm}+\mathrm{CARm} \leftrightarrow \mathrm{COAm}+\mathrm{ALCARm}$ & Down-regulate & 6 & 163 \\
\hline R23 & Pyruvate carboxylase & $\begin{array}{l}\mathrm{ATPm}+\mathrm{PYRm}+\mathrm{H}_{2} \mathrm{Om}+\mathrm{CO}_{2} \mathrm{~m} \rightarrow \mathrm{ADPm}+\mathrm{P} \\
\mathrm{Im}+\mathrm{OAm}+2^{*} \mathrm{Hm}\end{array}$ & Up-regulate & 6 & 163 \\
\hline NR20 & Acetyl-CoA:carnitine O-acetyltransferase & $\mathrm{ACCOA}+\mathrm{CAR} \leftrightarrow \mathrm{COA}+\mathrm{ALCAR}$ & Down-regulate & 6 & 163 \\
\hline R29 & Ribose-5-phosphate isomerase & $\mathrm{R} 5 \mathrm{P} \leftrightarrow \mathrm{RL} 5 \mathrm{P}$ & Down-regulate & 6 & 163 \\
\hline R765 & Nicotinate phosphoribosyltransferase & $\mathrm{NICA}+\mathrm{PRPP} \rightarrow \mathrm{NAMN}+\mathrm{PPI}$ & Down-regulate & 6 & 162 \\
\hline R240 & Phosphoglucomutase & $\mathrm{R} 5 \mathrm{P} \leftrightarrow \mathrm{R} 1 \mathrm{P}$ & Down-regulate & 6 & 162 \\
\hline R685 & Allantoicase & $\mathrm{ATT}+\mathrm{H}_{2} \mathrm{O} \leftrightarrow$ UGC + UREA & Down-regulate & 6 & 161 \\
\hline R644 & Nucleoside-diphosphate kinase & $A T P+D A D P \leftrightarrow A D P+D A T P$ & Down-regulate & 6 & 161 \\
\hline R764 & Nicotinamidase & $\mathrm{NICD}+\mathrm{H}_{2} \mathrm{O} \leftrightarrow \mathrm{NICA}+\mathrm{NH} 3$ & Down-regulate & 5 & 164 \\
\hline R397 & $\begin{array}{l}\text { 3-Carboxy-cis,cis-muconate cycloisomer- } \\
\text { ase }\end{array}$ & $3 C M U C O \leftrightarrow 4 C M U C L$ & Down-regulate & 5 & 163 \\
\hline R415 & $\begin{array}{l}\text { UDP-N-acetylglucosamine pyrophos- } \\
\text { phorylase }\end{array}$ & UTP + NAGA1P $\leftrightarrow P P I+U D P N A G$ & Down-regulate & 5 & 163 \\
\hline R512 & Phosphoserine transaminase & $\mathrm{PHP}+\mathrm{GLU} \rightarrow \mathrm{AKG}+3 \mathrm{PSER}$ & Down-regulate & 5 & 163 \\
\hline R607 & Proline dehydrogenase & $\mathrm{NADm}+\mathrm{PROm} \rightarrow 2^{*} \mathrm{Hm}+\mathrm{NADHm}+\mathrm{P} 5 \mathrm{Cm}$ & Down-regulate & 5 & 163 \\
\hline R684 & Allantoinase & $\mathrm{ATN}+\mathrm{H}_{2} \mathrm{O} \leftrightarrow$ ATT & Down-regulate & 5 & 163 \\
\hline R707 & Nucleoside-diphosphate kinase & $\mathrm{DUDP}+\mathrm{ATP} \leftrightarrow \mathrm{DUTP}+\mathrm{ADP}$ & Down-regulate & 5 & 163 \\
\hline R74 & Formate oxidase & $\mathrm{FOR}+\mathrm{O}_{2}+\mathrm{H} \rightarrow \mathrm{H}_{2} \mathrm{O}_{2}+\mathrm{CO}_{2}$ & Down-regulate & 5 & 163 \\
\hline R637 & IMP cyclohydrolase & PRFICA $\leftrightarrow \mathrm{H}_{2} \mathrm{O}+$ IMP & Down-regulate & 5 & 163 \\
\hline R699 & Nucleoside-diphosphate kinase & $\mathrm{CTP}+\mathrm{ADP} \leftrightarrow \mathrm{CDP}+\mathrm{ATP}$ & Down-regulate & 5 & 162 \\
\hline R630 & $\begin{array}{l}\text { Phosphoribosylglycinamide formyltrans- } \\
\text { ferase }\end{array}$ & $\mathrm{FTHF}+\mathrm{GAR} \rightarrow \mathrm{H}+\mathrm{THF}+\mathrm{FGAR}$ & Down-regulate & 5 & 161 \\
\hline R719 & Uracil phosphoribosyltransferase & $\mathrm{URA}+\mathrm{PRPP} \rightarrow \mathrm{UMP}+\mathrm{PPI}+\mathrm{H}$ & Down-regulate & 5 & 160 \\
\hline R730 & Cytosine deaminase & $\mathrm{CYTS}+\mathrm{H}_{2} \mathrm{O}+\mathrm{H} \rightarrow \mathrm{URA}+\mathrm{NH}_{3}$ & Down-regulate & 5 & 147 \\
\hline R306 & Ketohexokinase & $\mathrm{ATP}+\mathrm{FRU} \rightarrow \mathrm{ADP}+\mathrm{F} 1 \mathrm{P}+\mathrm{H}$ & Down-regulate & 4 & 163 \\
\hline R648 & Nucleoside-diphosphate kinase & $\mathrm{ATP}+\mathrm{GDP} \leftrightarrow \mathrm{ADP}+\mathrm{GTP}$ & Down-regulate & 4 & 163 \\
\hline R605 & Pyrroline-5-carboxylate reductase & $2^{*} \mathrm{H}+\mathrm{NADPH}+\mathrm{P} 5 \mathrm{C} \leftrightarrow \mathrm{PRO}+\mathrm{NADP}$ & Down-regulate & 4 & 163 \\
\hline R244 & Ribulokinase & $\mathrm{ATP}+\mathrm{RL} \rightarrow \mathrm{ADP}+\mathrm{RL} 5 \mathrm{P}+\mathrm{H}$ & Down-regulate & 4 & 163 \\
\hline R139 & 5-Formyltetrahydrofolate deformylase & $\mathrm{FTHF}+\mathrm{H}_{2} \mathrm{O} \rightarrow \mathrm{FOR}+\mathrm{THF}+\mathrm{H}$ & Down-regulate & 4 & 162 \\
\hline R511 & Phosphoglycerate dehydrogenase & $\mathrm{NAD}+3 \mathrm{PG} \leftrightarrow \mathrm{H}+\mathrm{NADH}+\mathrm{PHP}$ & Down-regulate & 4 & 162 \\
\hline R16 & Triosephosphate isomerase & $\mathrm{T} 3 \mathrm{P} 2 \leftrightarrow \mathrm{T} 3 \mathrm{P} 1$ & Down-regulate & 4 & 144 \\
\hline R27 & Phosphogluconate dehydrogenase & $\mathrm{D} 6 \mathrm{PGC}+\mathrm{NADP} \rightarrow \mathrm{RL} 5 \mathrm{P}+\mathrm{CO}_{2}+\mathrm{NADPH}$ & Up-regulate & 4 & 111 \\
\hline
\end{tabular}


Table 6 (continued)

\begin{tabular}{|c|c|c|c|c|c|}
\hline Reaction ID ${ }^{\mathrm{a}}$ & Name & Equation & Target & Frequency $^{b}$ & $\begin{array}{l}\text { Citric } \\
\text { \%increase }\end{array}$ \\
\hline R54 & Malate synthase & $\begin{array}{l}\text { ACCOAp }+\mathrm{H} 2 \mathrm{Op}+\mathrm{GLXp} \rightarrow \mathrm{MALp}+\mathrm{COAp} \\
+\mathrm{Hp}\end{array}$ & Up-regulate & 4 & 104 \\
\hline R450 & Cytochrome c oxidase & $\begin{array}{l}2^{*} \mathrm{FEROm}+0.5^{*} \mathrm{O}_{2} \mathrm{~m}+6^{*} \mathrm{Hm} \rightarrow 2^{*} \mathrm{FERIm}+\mathrm{H} \\
{ }_{2} \mathrm{Om}+4^{*} \mathrm{HoO}\end{array}$ & Up-regulate & 4 & 91 \\
\hline R658 & Purine nucleoside hydrolase & $\mathrm{ADN}+\mathrm{H}_{2} \mathrm{O} \rightarrow \mathrm{AD}+\mathrm{RIB}$ & Down-regulate & 3 & 163 \\
\hline R257 & D-arabinitol 2-dehydrogenase(NAD +) & $\mathrm{AOL}+\mathrm{NAD} \rightarrow \mathrm{RL}+\mathrm{NADH}+\mathrm{H}$ & Down-regulate & 3 & 163 \\
\hline R1215 & D-Glyceraldehyde:NAD + oxidoreductase & $\mathrm{G}+\mathrm{NADH}+2^{*} \mathrm{H} \leftrightarrow \mathrm{GLYAL}+\mathrm{NAD}+\mathrm{H}_{2} \mathrm{O}$ & Down-regulate & 3 & 163 \\
\hline R1233 & 3'-5'Bisphosphate nucleotidase & $\mathrm{PAP}+\mathrm{H}_{2} \mathrm{O} \rightarrow \mathrm{AMP}+\mathrm{PI}$ & Down-regulate & 3 & 162 \\
\hline R674 & Purine nucleosidase & $\mathrm{GSN}+\mathrm{H}_{2} \mathrm{O} \rightarrow \mathrm{GN}+\mathrm{RIB}$ & Down-regulate & 3 & 162 \\
\hline R769 & NAD synthetase & $\begin{array}{l}\mathrm{ATP}+\mathrm{DMNAD}+\mathrm{GLN}+\mathrm{H}_{2} \mathrm{O} \leftrightarrow \mathrm{AMP}+\mathrm{PPI}+ \\
\mathrm{NAD}+\mathrm{GLU}+2^{*} \mathrm{H}\end{array}$ & Down-regulate & 3 & 162 \\
\hline R266 & Gluconokinase & $\mathrm{GLCNT}+\mathrm{ATP} \rightarrow \mathrm{D} 6 \mathrm{PGC}+\mathrm{ADP}+\mathrm{H}$ & Down-regulate & 3 & 131 \\
\hline R413 & $\begin{array}{l}\mathrm{N} \text {-acetylglucosamine-6-phosphate } \\
\text { deacetylase }\end{array}$ & $\mathrm{NAGA} 6 \mathrm{P}+\mathrm{H}_{2} \mathrm{O} \rightarrow \mathrm{GA} 6 \mathrm{P}+\mathrm{AC}$ & Down-regulate & 3 & 126 \\
\hline R458 & ADP/ATP translocase & $\begin{array}{l}\mathrm{ADP}+\mathrm{PI}+\mathrm{ATPm}+\mathrm{H} 2 \mathrm{Om} \rightarrow \mathrm{ADPm}+\mathrm{PIm}+ \\
\mathrm{ATP}+\mathrm{H}_{2} \mathrm{O}\end{array}$ & Up-regulate & 3 & 111 \\
\hline R720 & dUTP pyrophosphatase & $\mathrm{DUTP}+\mathrm{H}_{2} \mathrm{O} \rightarrow \mathrm{PPI}+\mathrm{DUMP}+2^{*} \mathrm{H}$ & Down-regulate & 2 & 163 \\
\hline R675 & Guanine aminohydrolase & $\mathrm{GN}+\mathrm{H}_{2} \mathrm{O} \leftrightarrow \mathrm{XAN}+\mathrm{NH}_{3}$ & Down-regulate & 2 & 163 \\
\hline R1242 & Urea carboxylase & $\begin{array}{l}\text { UREA }+A T P+\mathrm{H}_{2} \mathrm{O}+\mathrm{CO}_{2} \leftrightarrow A D P+\mathrm{PI}+\text { URE } \\
\mathrm{AC}+2^{*} \mathrm{H}\end{array}$ & Down-regulate & 2 & 163 \\
\hline R189 & ATP:thiamine diphosphotransferase & $\mathrm{ATP}+\mathrm{THM} \rightarrow \mathrm{AMP}+\mathrm{THDP}+2^{*} \mathrm{H}$ & Down-regulate & 2 & 163 \\
\hline R1214 & Glycerate 3-kinase & $\mathrm{ATP}+\mathrm{G} \rightarrow \mathrm{ADP}+3 \mathrm{PG}+\mathrm{H}$ & Down-regulate & 2 & 162 \\
\hline R86 & Lactoylglutathione lyase & $R G T+M T H G X L \leftrightarrow L G T$ & Down-regulate & 2 & 144 \\
\hline R716 & Uridine kinase & $\mathrm{URI}+\mathrm{GTP} \rightarrow \mathrm{UMP}+\mathrm{GDP}+\mathrm{H}$ & Down-regulate & 2 & 134 \\
\hline R588 & Chorismate mutase & $\mathrm{CHOR} \rightarrow \mathrm{PHEN}$ & Down-regulate & 2 & 130 \\
\hline R695 & Nucleoside-diphosphate kinase & $\mathrm{UDP}+\mathrm{ATP} \leftrightarrow \mathrm{UTP}+\mathrm{ADP}$ & Down-regulate & 2 & 127 \\
\hline R446 & Respiratory-chain NADH dehydrogenase & $\begin{array}{l}\mathrm{NADH}+\mathrm{Qm}+5^{*} \mathrm{Hm} \rightarrow \mathrm{NAD}+\mathrm{QH} 2 \mathrm{~m}+4 \\
{ }^{*} \mathrm{Ho}\end{array}$ & Up-regulate & 2 & 107 \\
\hline R479 & Ornithine transaminase & $\mathrm{ORN}+\mathrm{AKG} \rightarrow \mathrm{GLUGSAL}+\mathrm{GLU}$ & Up-regulate & 2 & 93 \\
\hline R514 & Glycine hydroxymethyltransferase & $\mathrm{THF}+\mathrm{SER} \leftrightarrow \mathrm{H}_{2} \mathrm{O}+\mathrm{GLY}+\mathrm{METTHF}$ & Up-regulate & 2 & 90 \\
\hline R713 & ADP-ribose pyrophosphatase & $\mathrm{ADPR}+\mathrm{H}_{2} \mathrm{O} \rightarrow \mathrm{AMP}+\mathrm{R} 5 \mathrm{P}+2^{*} \mathrm{H}$ & Down-regulate & 2 & 90 \\
\hline R451 & ATP synthase & $\begin{array}{l}\mathrm{ADPm}+\mathrm{PIm}+4.5454^{*} \mathrm{Ho} \rightarrow \mathrm{ATPm}+\mathrm{H}_{2} \mathrm{Om} \\
+4.5454^{*} \mathrm{Hm}\end{array}$ & Up-regulate & 2 & 67 \\
\hline R76 & Pyruvate dehydrogenase & $\begin{array}{l}\mathrm{PYRm}+\mathrm{NADm}+\mathrm{COAm} \rightarrow \mathrm{ACCOAm}+\mathrm{NAD} \\
\mathrm{Hm}+\mathrm{CO}_{2} \mathrm{~m}+\mathrm{Hm}\end{array}$ & Up-regulate & 2 & 65 \\
\hline R105 & Glutamate decarboxylase & $\mathrm{GLUm}+\mathrm{Hm} \rightarrow \mathrm{GABAm}+\mathrm{CO}_{2} \mathrm{~m}$ & Down-regulate & 1 & 173 \\
\hline R515 & Threonine aldolase & $G L Y+A C A L \leftrightarrow T H R$ & Down-regulate & 1 & 163 \\
\hline R370 & Kynurenine formamidase & $\mathrm{FKYN}+\mathrm{H}_{2} \mathrm{O} \rightarrow \mathrm{FOR}+\mathrm{KYN}+\mathrm{H}$ & Down-regulate & 1 & 154 \\
\hline R1243 & Allophanate hydrolase & UREAC $+\mathrm{H}_{2} \mathrm{O} \rightarrow 2^{*} \mathrm{NH}_{3}+2^{*} \mathrm{CO}_{2}$ & Down-regulate & 1 & 153 \\
\hline R200 & Aldehyde dehydrogenase (NADP+) & $\begin{array}{l}\mathrm{ACALm}+\mathrm{NADPm}+\mathrm{H}_{2} \mathrm{Om} \rightarrow \mathrm{ACm}+\mathrm{NAD}- \\
\mathrm{PHm}+2^{*} \mathrm{Hm}\end{array}$ & Down-regulate & 1 & 133 \\
\hline R135 & $\begin{array}{l}\text { Methylenetetrahydrofolate dehydrogenase } \\
(\mathrm{NADP}+)\end{array}$ & $\mathrm{METHFm}+\mathrm{NADPHm} \leftrightarrow \mathrm{METTHFm}+\mathrm{NADPm}$ & Up-regulate & 1 & 116 \\
\hline R784 & 5'-Nucleotidase & $\mathrm{NAMN}+\mathrm{H}_{2} \mathrm{O} \rightarrow \mathrm{NAR}+\mathrm{PI}$ & Up-regulate & 1 & 115 \\
\hline R728 & Cytidine deaminase & $\mathrm{CYTD}+\mathrm{H}_{2} \mathrm{O} \rightarrow \mathrm{URI}+\mathrm{NH}_{3}$ & Down-regulate & 1 & 114 \\
\hline R211 & $\begin{array}{l}\text { Glycerol 3-phosphate dehydrogenase } \\
\text { (NAD+ dependent) }\end{array}$ & $\mathrm{H}+\mathrm{T} 3 \mathrm{P} 2+\mathrm{NADH} \rightarrow \mathrm{GL} 3 \mathrm{P}+\mathrm{NAD}$ & Up-regulate & 1 & 113 \\
\hline R337 & Phenylacetaldehyde dehydrogenase & $\begin{array}{l}\mathrm{PHAL}+\mathrm{NADP}+\mathrm{H}_{2} \mathrm{O} \leftrightarrow \mathrm{PHAC}+\mathrm{NADPH}+ \\
2^{*} \mathrm{H}\end{array}$ & Down-regulate & 1 & 113 \\
\hline R205 & Glycerol dehydrogenase & $\mathrm{H}+\mathrm{GLYAL}+\mathrm{NADPH} \rightarrow \mathrm{GL}+\mathrm{NADP}$ & Down-regulate & 1 & 112 \\
\hline R53 & Isocitrate lyase & $\mathrm{ICITp} \rightarrow \mathrm{SUCCp}+\mathrm{GLXp}$ & Up-regulate & 1 & 111 \\
\hline
\end{tabular}


Table 6 (continued)

\begin{tabular}{|c|c|c|c|c|c|}
\hline Reaction ID ${ }^{a}$ & Name & Equation & Target & Frequency $^{\mathbf{b}}$ & $\begin{array}{l}\text { Citric } \\
\text { \%increase }\end{array}$ \\
\hline R445 & Respiratory-chain NADH dehydrogenase & $\begin{array}{l}\mathrm{NADHm}+\mathrm{Qm}+5^{*} \mathrm{Hm} \rightarrow \mathrm{NADm}+\mathrm{QH} 2 \mathrm{~m} \\
+4^{*} \mathrm{Ho}\end{array}$ & Up-regulate & 1 & 103 \\
\hline R28 & Ribulose-phosphate 3-epimerase & $\mathrm{RL} 5 \mathrm{P} \leftrightarrow \mathrm{XUL5P}$ & Up-regulate & 1 & 100 \\
\hline R40 & Isocitrate dehydrogenase (NADP+) & $\mathrm{ICIT}+\mathrm{NADP} \rightarrow \mathrm{AKG}+\mathrm{CO} 2+\mathrm{NADPH}$ & Up-regulate & 1 & 96 \\
\hline R39 & Isocitrate dehydrogenase (NAD+) & $\mathrm{ICITm}+\mathrm{NADm} \rightarrow \mathrm{AKGm}+\mathrm{CO} 2 \mathrm{~m}+\mathrm{NADHm}$ & Up-regulate & 1 & 96 \\
\hline R725 & 5'-Nucleotidase & $\mathrm{UMP}+\mathrm{H}_{2} \mathrm{O} \rightarrow \mathrm{PI}+\mathrm{URI}$ & Up-regulate & 1 & 95 \\
\hline R137 & $\begin{array}{l}\text { Methylenetetrahydrofolate dehydrogenase } \\
(\mathrm{NAD+})\end{array}$ & $\mathrm{METTHF}+\mathrm{NAD} \rightarrow \mathrm{METHF}+\mathrm{NADH}$ & Up-regulate & 1 & 92 \\
\hline R38 & Isocitrate dehydrogenase (NADP+) & $\begin{array}{l}\mathrm{ICITm}+\mathrm{NADPm} \rightarrow \mathrm{AKGm}+\mathrm{CO}_{2} \mathrm{~m}+\mathrm{NAD}- \\
\mathrm{PHm}\end{array}$ & Up-regulate & 1 & 63 \\
\hline R477 & Argininosuccinate synthase & $\begin{array}{l}\mathrm{ASP}+\mathrm{ATP}+\mathrm{CITR} \rightarrow 2^{*} \mathrm{H}+\mathrm{AMP}+\mathrm{PPI}+\mathrm{ARG}- \\
\mathrm{SUCC}\end{array}$ & Up-regulate & 1 & 53 \\
\hline R238 & Dihydroxyacetone synthase & $\mathrm{XUL5P}+\mathrm{FALD} \leftrightarrow \mathrm{T} 3 \mathrm{P} 1+\mathrm{GLYN}$ & Up-regulate & 1 & 53 \\
\hline R376 & 4-Hydroxyphenylpyruvate dioxygenase & $4 \mathrm{HPP}+\mathrm{O}_{2} \rightarrow \mathrm{HOMOGEN}+\mathrm{CO}_{2}$ & Down-regulate & N/A & 150 \\
\hline R78 & Pyruvate decarboxylase & $\mathrm{H}+\mathrm{PYR} \rightarrow \mathrm{ACAL}+\mathrm{CO}_{2}$ & Up-regulate & N/A & 80 \\
\hline R199 & Aldehyde dehydrogenase (NAD+) & $\begin{array}{l}\mathrm{ACALm}+\mathrm{NADm}+\mathrm{H} 2 \mathrm{Om} \rightarrow \mathrm{ACm}+\mathrm{NADH} \\
\mathrm{m}+2^{*} \mathrm{Hm}\end{array}$ & Down-regulate & N/A & 57 \\
\hline
\end{tabular}

${ }^{a}$ The ID of the reaction in the iDU1327 metabolic model (see Additional file 1)

${ }^{b}$ The number of runs of in silico evolution the target occurred in. Where the frequency is marked as N/A, the target occurred in a subsequent run with mutations disallowed on previously targeted reactions

'The percentage increase in citric acid output flux at $\mathrm{T} 2$ when the flux bounds of the reaction are set to their original unconstrained values while retaining the constrained flux bounds of the other reactions in the solution. If the given reaction is present in multiple solutions, the highest percentage increase is given

for 3 min to pellet the biomass, and the supernatant was aspirated without disruption of the biomass pellet.

\section{Dynamic modelling to simulate the fermentation of bagasse hydrolysate to citric acid}

Dynamic modelling was done as described previously [17] with some modifications. In brief, the FBA calculations were performed using bespoke Java code which implements the GLPK toolkit (GNU). dFBA routines were written directly into the Java code with the differential equations representing transport reactions solved by simple time-stepping (Euler method) with small values for the time-step. The iDU1756 model [19] was used, and deletions of the pyrG, gox, and oah genes were simulated by setting the flux bounds of their corresponding reactions to zero. Nitrate was used as the nitrogen input and uridine input was enabled. The sequential uptake of glucose and xylose was modelled by disabling xylose transport-mediated uptake at external glucose concentrations above $5 \mathrm{mM}$; the threshold of $5 \mathrm{mM}$ was applied as this gave the best fit to the in vivo data. The kinetic parameters applied in the model are given in Table 7. The dFBA start time was adjusted to $10 \mathrm{~h}$ after inoculation.

\section{Sampling for transcriptome analysis and isolation of RNA for RNA-Seq}

Cultures were setup as described previously. For the timepoints T1, T2, and T3, cultures were harvested in biological triplicates at 21,72 , and $132 \mathrm{~h}$, respectively. Cultures were harvested as follows: The flask contents were filtered through a double layer of Miracloth to separate the mycelia from the culture liquid. The mycelia were washed 2 times in chilled $100 \mathrm{mM}$ Tris. $\mathrm{HCl}$ buffer $\mathrm{pH} 7.5$ $(\approx 150 \mathrm{~mL}$ per wash $)$ and then 3 times in chilled $\mathrm{dH}_{2} \mathrm{O}$ $(\approx 150 \mathrm{~mL}$ per wash). Washed mycelia were squeezedried in Miracloth and transferred to $50 \mathrm{~mL}$ Falcon tubes on ice and then flash frozen in liquid nitrogen followed by storage at $-80{ }^{\circ} \mathrm{C}$. Samples were freeze-dried overnight prior to use for RNA isolation and stored at $-80{ }^{\circ} \mathrm{C}$ thereafter. RNA was extracted and purified: For each sample, $5 \mathrm{mg}$ freeze-dried mycelia were added to a precooled $2 \mathrm{~mL}$ Eppendorf tube with two $3 \mathrm{~mm}$ tungsten carbide beads. The tubes were dipped in liquid nitrogen and kept on ice. Freeze-dried mycelia were ground using a TissueLyser set to $30 \mathrm{~Hz}$ for $30 \mathrm{~s}$ four times. $1 \mathrm{~mL}$ TRIzol reagent was added to each sample of ground mycelia followed by agitation using a TissueLyser set to $30 \mathrm{~Hz}$ for $30 \mathrm{~s}$ four times. RNA was extracted by the TRIzol method (Thermo Fisher Scientific) according to the manufacturer's instructions. RNA pellets were air-dried at $37{ }^{\circ} \mathrm{C}$ 
Table 7 Kinetic parameters applied in dynamic modelling of sugarcane bagasse hydrolysate fermentation

\begin{tabular}{|c|c|c|}
\hline Parameter & Description & Value \\
\hline$V_{P e, \max }\left(m m o l g W^{-1} h^{-1}\right)$ & External phosphate maximum input rate & 0.15 \\
\hline$K_{P e}(\mathrm{mM})$ & External phosphate Michaelis constant & $0.0333^{\mathrm{a}}$ \\
\hline 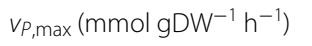 & Internal phosphate maximum input rate & 0.06 \\
\hline$K_{p}(\mathrm{mM})$ & Internal phosphate Michaelis constant & 20 \\
\hline$v_{G 1}\left(m m o l g D W^{-1} h^{-1}\right)$ & External glucose passive uptake rate & $0.0027 \times[G L C]^{b}$ \\
\hline$v_{G 2, \max }\left(\mathrm{mmol} \mathrm{gDW} \mathrm{W}^{-1} \mathrm{~h}^{-1}\right)$ & External glucose transport-mediated uptake maximum rate & 0.08 \\
\hline$K_{G 2}(\mathrm{mM})$ & External glucose transport-mediated uptake Michaelis constant & $0.26^{\mathrm{a}}$ \\
\hline$K_{i 2}(\mathrm{mM})$ & External glucose transport-mediated uptake citrate inhibition constant & $933^{\mathrm{a}}$ \\
\hline$v_{x_{1}}\left(\mathrm{mmol} \mathrm{gDW}^{-1} \mathrm{~h}^{-1}\right)$ & External xylose passive uptake rate & $0.00027 \times[X Y L]^{c}$ \\
\hline$v \times 2$, max $\left(m m o l g D W^{-1} \mathrm{~h}^{-1}\right)$ & External xylose transport-mediated uptake maximum rate & 0.18 \\
\hline$K_{\times 2}(\mathrm{mM})$ & External xylose transport-mediated uptake Michaelis constant & $3.33^{\mathrm{a}}$ \\
\hline$v_{\text {CIT }}\left(m m o l g D W^{-1} h^{-1}\right)$ & Citric acid output rate constraint $^{d}$ & $0.12^{\mathrm{a}}$ \\
\hline
\end{tabular}

${ }^{a}$ These values are the same as in the dynamic modelling reported previously [17]

${ }^{b}[G L C]$ is the concentration of external glucose in $\mathrm{mM}$

${ }^{c}[X Y L]$ is the concentration of external xylose in $\mathrm{mM}$

${ }^{\mathrm{d}}$ Citric acid output rate constraint was only applied $32 \mathrm{~h}$ after the start time

for $10 \mathrm{~min}$ and solubilised in $200 \mu \mathrm{l}$ RNase-free water at $60{ }^{\circ} \mathrm{C}$ for $15 \mathrm{~min}$. RNA samples were stored at $-80{ }^{\circ} \mathrm{C}$. RNA samples were further purified using the TURBO DNA-free ${ }^{\mathrm{TM}}$ kit (Thermo Fisher Scientific) according to the manufacturer's instructions. RNA samples were sent to the University of York Technology Facility for RNASeq library preparation by poly(A) purification, and libraries were sequenced at the University of Leeds Next Generation Sequencing Facility using an Illumina HiSeq 3000 platform with $2 \times 150$ bp sequencing.

\section{Bioinformatics processing of RNA-Seq data}

The tools used to construct the reference transcriptome were HISAT2 [23], StringTie [24], Mikado [25], Portcullis [26], and TransDecoder [27]. The latest version ( $\mathrm{v} 4.0$ ) of the A. niger ATCC1015 genome annotation [28] available from the Joint Genome Institute was used. The mitochondrial transcripts determined for the $A$. niger strain N909 [29] were included in the reference transcriptome. The tools used to perform quantification and differential expression analysis were Salmon [30], Wasabi [31], and Sleuth [32]. Figure 5 shows the workflow followed to process the RNA-Seq data.

\section{Functional annotation of transcripts and generation} of transcript-reaction associations for the iDU1327 model The gene-protein-reaction associations in the iDU1756 model [19] were replaced with transcript-reaction associations in the model iDU1327 (see Additional file 1), determined by a comprehensive functional annotation process that employed a multitude of tools (Table 8). Mapping files (Table 9) and the KEGG database [53] were used to map the output from each tool to gene ontology $(\mathrm{GO})$ molecular functions, EC numbers, and KEGG reactions. A consensus functional annotation was built, and KEGG reactions were included if associated with an EC number in the consensus. Figure 6 shows the workflow followed to construct the consensus functional annotation.

\section{Mapping transcript expression to a reaction-level}

The transcript expression data were mapped to a reaction-level following the transcript-reaction associations in iDU1327 and according to the following rules: In the case of an OR relationship, the expression of associated transcripts was summed. In the case of an AND relationship, the minimum expression of associated transcripts was taken. Reactions with expression below the cut-off $(\mathrm{TPM}<1)$ were switched off.

\section{Transcriptome-guided in silico evolution of constrained citric production}

The in silico evolution of constrained citric production was performed using an evolutionary algorithm implemented in Java [19] with changes made to the fitness function and mutation operator as detailed below:

\section{(i) Fitness function}

The fitness was calculated with respect to $\mathrm{T} 2$ by a leastsquares fitting procedure

$$
F=-\log _{10} \sum\left(f_{t}-f_{a}\right)^{2}
$$




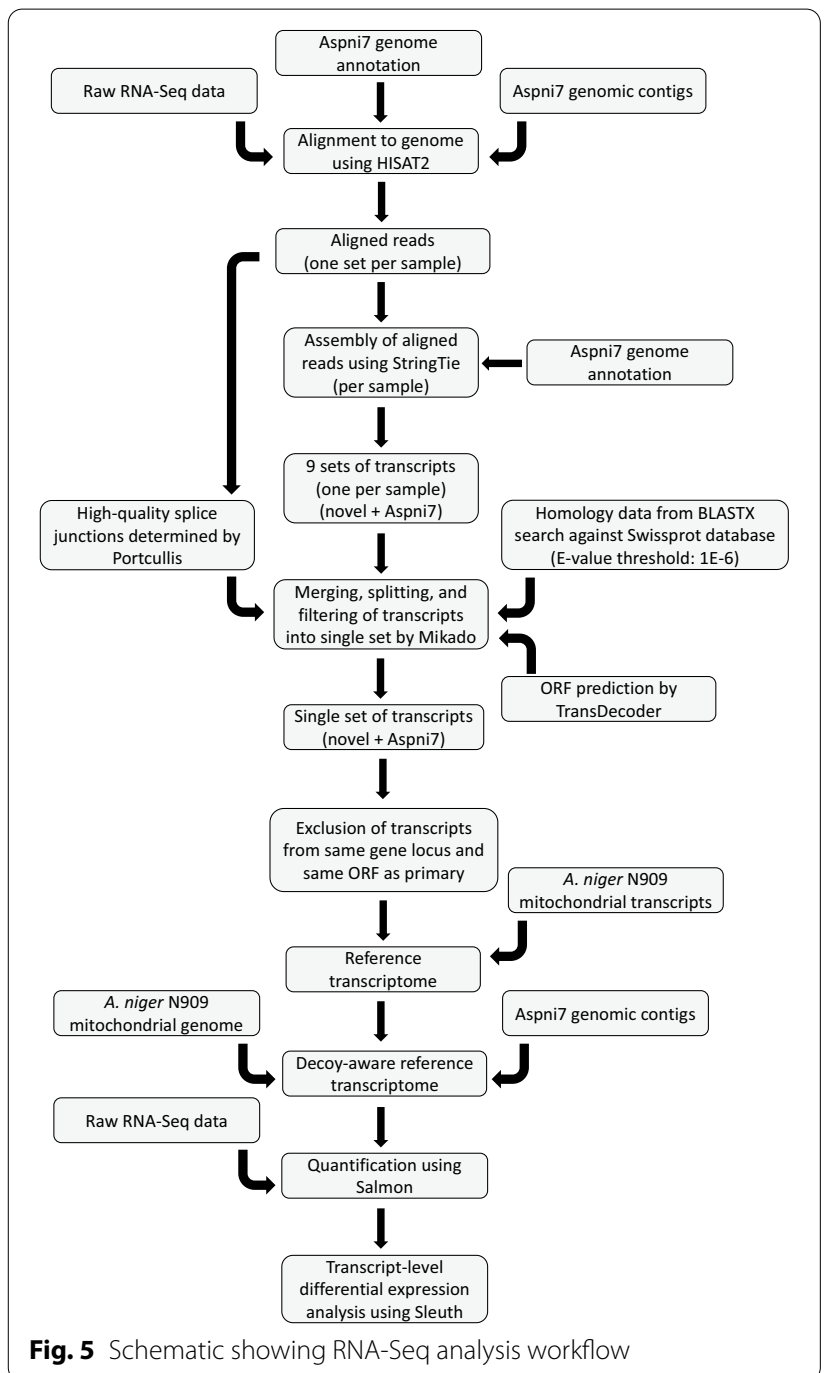

Table 8 Tools used in functional annotation of transcripts

\begin{tabular}{lll}
\hline Name of tool & References & $\begin{array}{l}\text { \%Transcripts } \\
\text { annotated }\end{array}$ \\
\hline KEGG Automatic Annotation Server (KAAS) & {$[33]$} & 32.6 \\
InterProScan & {$[34]$} & 71.1 \\
Blast2GO & {$[35]$} & 56.1 \\
Batch CD-Search against COG database & {$[36-38]$} & 45.9 \\
Batch CD-Search against PFAM database & {$[36,37,39]$} & 68.6 \\
Batch CD-Search against SMART database & {$[36,37,40]$} & 22.1 \\
Batch CD-Search against TIGR database & {$[36,37,41]$} & 30.3 \\
ScanProsite & {$[42]$} & 35.8 \\
BLASTP search against BRENDA database & {$[43,44]$} & 24.1 \\
(thresholds: 60\% identify, E-value 1E-6) & & \\
HAMAP-Scan & {$[45]$} & 2.6 \\
GOFEAT (threshold: E-value 1E-5) & {$[46]$} & 66.9 \\
EFICAz ${ }^{2.5}$ & {$[47]$} & 19.4 \\
TransAAP & {$[48]$} & 6.8 \\
\hline
\end{tabular}

where $F$ is the fitness, $f_{t}$ is the target flux, and $f_{a}$ is the actual flux.

The fluxes included were those for five exchange reactions (internal phosphate, glucose, xylose, biomass, and citric acid). The target citric output flux was set to 0.12 in line with in vivo data, and the other target fluxes were set to their original values.

\section{(ii) Mutation operator}

Flux bounds were subjected to change by the mutation operator, informed by differential expression events (fold change $\geq 2$ ) at both $\mathrm{T} 1$ to $\mathrm{T} 2$ and $\mathrm{T} 2$ to $\mathrm{T} 3$, and resulted in flux either being constrained (down-regulation), forced (up-regulation), or unchanged (no differential expression). Mutations were permitted to alter flux bounds within the multiplicative bounds determined by the fold change in expression and fluxes at T1 and T3, with the effect of imposing a limit on the extent of flux constraint and a minimum value for forcing flux. Mutations were not allowed to force flux on reactions without a clear direction of flux or beyond the maximum allowable flux. For initial mutations, the flux bound was set randomly between the minimum flux forced and the maximum allowable flux if forcing flux or between the original flux and the limit of flux constraint if constraining flux. For subsequent mutations, the flux bound was mutated from the existing mutated flux bound. Mutations constraining flux were applied to both lower and upper bounds for reversible reactions. Mutations were performed by adding a small value to the flux bound determined by the double Laplace function. The location parameter, $\mu$, was set to zero, and the scale parameter, $b$, was set according to

$$
\begin{aligned}
b & =0.01|B|,|B|>0 \\
b & =0.001,|B|=0,
\end{aligned}
$$

where $b$ is the scale parameter, and $B$ is the flux bound that the mutation is applied to.

\section{(iii) Driving evolution of multiple solutions}

A fitness threshold of 6 was applied to identify evolved solutions, and these were analysed to identify their key reactions. This threshold was chosen as at this fitness value the fluxes of selected exchange reactions are sufficiently close to their target values. Each mutated flux bound was evaluated for its contribution to the fitness by complementation with the original flux bound, and the reaction corresponding to the mutation with the greatest contribution to fitness was identified as the key reaction. Flux bounds of the key reaction were then reset to the original across the population and blocked from mutating again. The in silico evolution was run for 150,000 
Table 9 Mapping files used in functional annotation of transcripts

\begin{tabular}{|c|c|c|c|}
\hline Name of mapping file & Source & Date & References \\
\hline ec2go & http://current.geneontology.org/ontology/external2go/ec2go & 2020/06/01 & [49] \\
\hline pfam2go & http://geneontology.org/external2go/pfam2go & 2020/04/18 & {$[50]$} \\
\hline prosite2go & http://current.geneontology.org/ontology/external2go/prosite2go & $2020 / 04 / 18$ & [50] \\
\hline smart2go & http://current.geneontology.org/ontology/external2go/smart2go & $2020 / 04 / 18$ & [50] \\
\hline hamap2go & http://current.geneontology.org/ontology/external2go/hamap2go & $2020 / 04 / 18$ & [51] \\
\hline rhea2kegg_reaction.tsv & https://ftp.expasy.org/databases/rhea/tsv/rhea2kegg_reaction.tsv & $2020 / 07 / 10$ & [52] \\
\hline TIGRFAMS_GO_LINK & ftp://ftp.jcvi.org/pub/data/TIGRFAMs/ & $2014 / 09 / 17$ & [41] \\
\hline TIGRFAMs Complete Listing & http://tigrfams.jcvi.org/cgi-bin/Listing.cgi & 2014/09/17 & [41] \\
\hline ko2cog.xl & https://www.genome.jp/kegg/files/ko2cog.xl & $2020 / 07 / 02$ & [53] \\
\hline ko2go.xl & https://www.genome.jp/kegg/files/ko2go.xl & 2020/07/02 & [53] \\
\hline ko2tc.xl & https://www.genome.jp/kegg/files/ko2tc.xl & 2020/07/10 & [53] \\
\hline
\end{tabular}

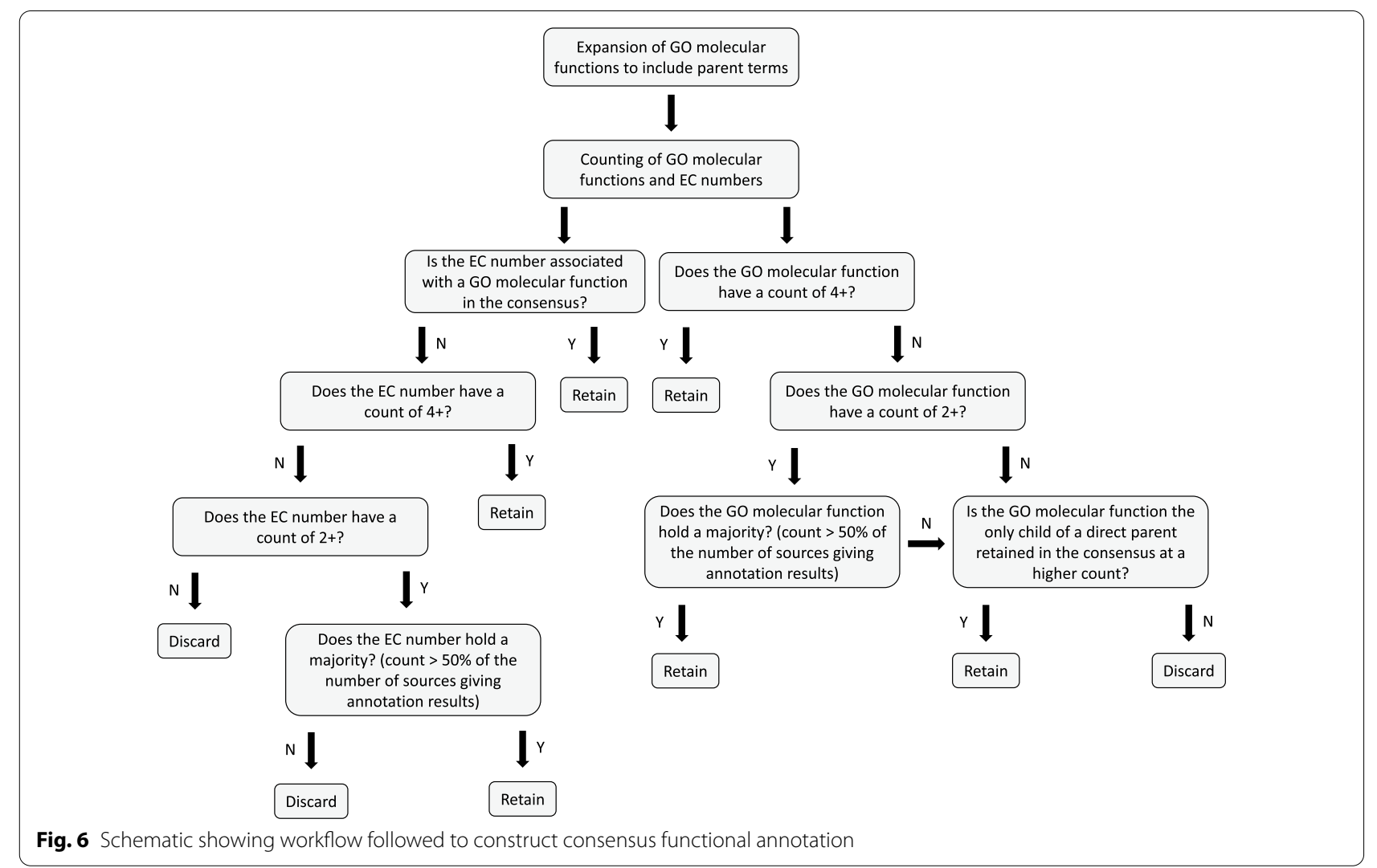

generations, a duration sufficient to allow for the evolution of multiple solutions.

\section{Processing solutions from in silico evolution to suggest targets for strain optimisation}

Solutions from in silico evolution were subjected to optimisation and simplification. Mutated flux bounds were evaluated for their contribution to the solution fitness by resetting them to the original flux bounds, and the mutations were removed if the solution fitness remained over a threshold of 6 . Additionally, the mutations on a reaction's flux bounds were optimised by making small adjustments. Processed solutions were analysed to rank their mutations by contribution to the solution fitness, by individually complementing the mutated flux bounds on each reaction with the original flux bounds. Key 
reactions were identified by proceeding down the ranked list and successively removing mutations until citric acid output flux increased close to its original unconstrained value. For this purpose, a revised fitness was computed by substituting the target citric acid output flux of 0.12 with the original unconstrained value, and a threshold of 3.5 was applied for the revised fitness to identify the set of key reactions that when returned to their original flux bounds result in optimal citric production. This threshold was chosen as at this fitness value the fluxes of selected exchange reactions are sufficiently close to values that reflect optimal citric production. A set of key reactions was obtained from each processed solution, and from these target suggestions were sourced. A threshold of $50 \%$ increase in citric acid output flux at T2 was applied to identify prominent suggested targets that have significant effect in silico.

\section{Supplementary Information}

The online version contains supplementary material available at https://doi. org/10.1186/s13068-021-02099-2.

Additional file 1: The iDU1327 model presented as a spreadsheet.

\section{Acknowledgements}

Not applicable.

\section{Authors' contributions}

DJU conceptualised the study, developed the methodology and software, performed the experiments, analysed the data, and wrote the original draft of the manuscript. MK assisted with data analysis. CW, LF, and LDG developed the methodology for producing bagasse hydrolysate. SJMM, SS, and AJW acquired the funding, supervised the work, and reviewed and edited the manuscript. All authors read and approved the final manuscript.

\section{Funding}

This work was supported by the Biotechnology and Biological Sciences Research Council (BBSRC) [Grant Number BB/S01196X/1], the Department of Biotechnology (DBT), Ministry of Science and Technology, Government of India [Grant Number BT/IN/Indo-UK/SSY/07/2018-19], and Innovate UK [Grant Number 104336].

\section{Availability of data and materials}

The datasets used and/or analysed during the current study are available from the corresponding author on reasonable request.

\section{Declarations}

Ethics approval and consent to participate

Not applicable.

\section{Consent for publication}

Not applicable.

\section{Competing interests}

The authors declare that they have no competing interests.

\section{Author details}

'Department of Biology, University of York, Wentworth Way, York YO10 5DD, UK. ${ }^{2}$ Systems Biology for Biofuel Group, International Centre for Genetic Engineering and Biotechnology (ICGEB), ICGEB Campus, Aruna Asaf Ali Marg,
New Delhi 110067, India. ${ }^{3}$ Department of Mathematics, University of York, Heslington, York YO10 5DD, UK.

Received: 4 November 2021 Accepted: 24 December 2021

Published online: 12 January 2022

\section{References}

1. Ciriminna R, Meneguzzo F, Delisi R, Pagliaro M. Citric acid: emerging applications of key biotechnology industrial product. Chem Cent J. 2017;11:1-9.

2. Meyer V, Wu B, Ram AF. Aspergillus as a multi-purpose cell factory: current status and perspectives. Biotechnol Lett. 2011;33:469-76.

3. Yang L, Henriksen MM, Hansen RS, Lübeck M, Vang J, Andersen JE, Bille S, Lübeck PS. Metabolic engineering of Aspergillus niger via ribonucleoprotein-based CRISPR-Cas9 system for succinic acid production from renewable biomass. Biotechnol Biofuels. 2020;13:1-12.

4. Hossain AH, Li A, Brickwedde A, Wilms L, Caspers M, Overkamp K, Punt PJ. Rewiring a secondary metabolite pathway towards itaconic acid production in Aspergillus niger. Microb Cell Fact. 2016;15:1-5.

5. Dhillon GS, Brar SK, Kaur S, Verma M. Screening of agro-industrial wastes for citric acid bioproduction by Aspergillus niger NRRL 2001 through solid state fermentation. J Sci Food Agr. 2013;93:1560-7.

6. Lu H, Cao W, Ouyang L, Xia J, Huang M, Chu J, Zhuang Y, Zhang S, Noorman $\mathrm{H}$. Comprehensive reconstruction and in silico analysis of Aspergillus niger genome-scale metabolic network model that accounts for 1210 ORFs. Biotechnol Bioeng. 2017;114:685-95.

7. Hassan SS, Williams GA, Jaiswal AK. Moving towards the second generation of lignocellulosic biorefineries in the EU: drivers, challenges, and opportunities. Renew Sust Energ Rev. 2019;101:590-9.

8. Bezerra TL, Ragauskas AJ. A review of sugarcane bagasse for secondgeneration bioethanol and biopower production. Biofuel Bioprod Bior. 2016;10:634-47.

9. Xie H, Ma Q, Wei DZ, Wang FQ. Transcriptomic analysis of Aspergillus niger strains reveals the mechanism underlying high citric acid productivity. Bioresour Bioprocess. 2018;5:1-23.

10. Becker SA, Palsson BO. Context-specific metabolic networks are consistent with experiments. PLoS Comput Biol. 2008;4:e1000082.

11. Colijn C, Brandes A, Zucker J, Lun DS, Weiner B, Farhat MR, Cheng TY, Moody DB, Murray M, Galagan JE. Interpreting expression data with metabolic flux models: predicting Mycobacterium tuberculosis mycolic acid production. PLoS Comput Biol. 2009;5:e1000489.

12. Chandrasekaran S, Price ND. Probabilistic integrative modeling of genome-scale metabolic and regulatory networks in Escherichia coli and Mycobacterium tuberculosis. P Natl Acad Sci USA. 2010;107:17845-50.

13. Zur H, Ruppin E, Shlomi T. iMAT: an integrative metabolic analysis tool. Bioinformatics. 2010;26:3140-2.

14. Jensen PA, Papin JA. Functional integration of a metabolic network model and expression data without arbitrary thresholding. Bioinformatics. 2011;27:541-7.

15. Kim MK, Lane A, Kelley JJ, Lun DS. E-Flux2 and SPOT: validated methods for inferring intracellular metabolic flux distributions from transcriptomic data. PLOS ONE. 2016;11:e0157101.

16. Tian M, Reed JL. Integrating proteomic or transcriptomic data into metabolic models using linear bound flux balance analysis. Bioinformatics. 2018;34:3882-8.

17. Upton DJ, McQueen-Mason SJ, Wood AJ. An accurate description of Aspergillus niger organic acid batch fermentation through dynamic metabolic modelling. Biotechnol Biofuels. 2017;10:1-14.

18. Peksel A, Torres N, Liu J, Juneau G, Kubicek C. 13 C-NMR analysis of glucose metabolism during citric acid production by Aspergillus niger. Appl Microbiol Biot. 2002;58:157-63.

19. Upton DJ, McQueen-Mason SJ, Wood AJ. In silico evolution of Aspergillus niger organic acid production suggests strategies for switching acid output. Biotechnol Biofuels. 2020;13:1-21.

20. Steiger MG, Rassinger A, Mattanovich D, Sauer M. Engineering of the citrate exporter protein enables high citric acid production in Aspergillus niger. Metab Eng. 2019;52:224-31.

21. XuY, Shan L, Zhou Y, Xie Z, Ball AS, Cao W, Liu H. Development of a Cre-lox P-based genetic system in Aspergillus niger ATCC1015 and its 
application to construction of efficient organic acid-producing cell factories. Appl Microbiol Biot. 2019;103:8105-14.

22. Wang L, Zhang J, Cao Z, Wang Y, Gao Q, Zhang J, Wang D. Inhibition of oxidative phosphorylation for enhancing citric acid production by Aspergillus niger. Microb Cell Fact. 2015;14:1-12.

23. Kim D, Paggi JM, Park C, Bennett C, Salzberg SL. Graph-based genome alignment and genotyping with HISAT2 and HISAT-genotype. Nat Biotechnol. 2019;37:907-15.

24. Pertea M, Pertea GM, Antonescu CM, Chang TC, Mendell JT, Salzberg SL. StringTie enables improved reconstruction of a transcriptome from RNAseq reads. Nat Biotechnol. 2015;33:290-5.

25. Venturini L, Caim S, Kaithakottil GG, Mapleson DL, Swarbreck D. Leveraging multiple transcriptome assembly methods for improved gene structure annotation. GigaScience. 2018;7:giy093.

26. Mapleson D, Venturini L, Kaithakottil G, Swarbreck D. Efficient and accurate detection of splice junctions from RNA-seq with Portcullis. GigaScience. 2018;7:giy131.

27. GitHub-TransDecoder/TransDecoder:TransDecoder source. https:// github.com/TransDecoder/TransDecoder. Accessed 19 June 2020

28. Andersen MR, Salazar MP, Schaap PJ, van de Vondervoort PJ, Culley D, Thykaer J, Frisvad JC, Nielsen KF, Albang R, Albermann K, Berka RM. Comparative genomics of citric-acid-producing Aspergillus niger ATCC 1015 versus enzyme-producing CBS 513.88. Genome Res. 2011;21:885-97.

29. Juhász Á, Pfeiffer I, Keszthelyi A, Kucsera J, Vágvölgy C, Hamari Z. Comparative analysis of the complete mitochondrial genomes of Aspergillus niger mtDNA type $1 \mathrm{a}$ and Aspergillus tubingensis mtDNA type 2b. FEMS Microbiol Lett. 2008;281:51-7.

30. Patro R, Duggal G, Love MI, rizarry RA, Kingsford C. Salmon provides fast and bias-aware quantification of transcript expression. Nat Methods. 2017;14:417-9.

31. GitHub-COMBINE-lab/wasabi: prepare Sailfish and Salmon output for downstream analysis. https://github.com/COMBINE-lab/wasabi. Accessed 24 June 2020.

32. Pimentel H, Bray NL, Puente S, Melsted P, Pachter L. Differential analysis of RNA-seq incorporating quantification uncertainty. Nat Methods. 2017; 14:687-90.

33. Moriya Y, Itoh M, Okuda S, Yoshizawa AC, Kanehisa M. KAAS: an automatic genome annotation and pathway reconstruction server. Nucleic Acids Res. 2007;35:W182-5.

34. Blum M, Chang HY, Chuguransky S, Grego T, Kandasaamy S, Mitchell A, Nuka G, Paysan-Lafosse T, Qureshi M, Raj S, Richardson L. The InterPro protein families and domains database: 20 years on. Nucleic Acids Res. 2021:49:D344-54

35. Conesa A, Götz S, García-Gómez JM, Terol J, Talón M, Robles M. Blast2GO: a universal tool for annotation, visualization and analysis in functional genomics research. Bioinformatics. 2005;21:3674-6.

36. Marchler-Bauer A, Bryant SH. CD-Search: protein domain annotations on the fly. Nucleic Acids Res. 2004;32:W327-31.

37. Marchler-Bauer A, Lu S, Anderson JB, Chitsaz F, Derbyshire MK, DeWeeseScott C, Fong JH, Geer LY, Geer RC, Gonzales NR, Gwadz M. CDD: a Conserved Domain Database for the functional annotation of proteins. Nucleic Acids Res. 2010;39:D225-9.

38. Tatusov RL, Galperin MY, Natale DA, Koonin EV. The COG database: a tool for genome-scale analysis of protein functions and evolution. Nucleic Acids Res. 2000;28:33-6.

39. Finn RD, Bateman A, Clements J, Coggill P, Eberhardt RY, Eddy SR, Heger A, Hetherington K, Holm L, Mistry J, Sonnhammer EL. Pfam: the protein families database. Nucleic Acids Res. 2014;42:D222-30.

40. Letunic I, Bork P. 20 years of the SMART protein domain annotation resource. Nucleic Acids Res. 2018:46:D493-6.

41. Haft DH, Selengut JD, Richter RA, Harkins D, Basu MK, Beck E. TIGRFAMs and genome properties in 2013. Nucleic Acids Res. 2012:41:D387-95.

42. De Castro E, Sigrist CJ, Gattiker A, Bulliard V, Langendijk-Genevaux PS, Gasteiger E, Bairoch A, Hulo N. ScanProsite: detection of PROSITE signature matches and ProRule-associated functional and structural residues in proteins. Nucleic Acids Res. 2006;34:W362-5.

43. Jeske L, Placzek S, Schomburg I, Chang A, Schomburg D. BRENDA in 2019: a European ELIXIR core data resource. Nucleic Acids Res. 2019;47:D542-9.

44. Enzyme Database-BRENDA. www.brenda-enzymes.org. Accessed 7 July 2020
45. Pedruzzi I, Rivoire C, Auchincloss AH, Coudert E, Keller G, De Castro E, Baratin D, Cuche BA, Bougueleret L, Poux S, Redaschi N. HAMAP in 2015 updates to the protein family classification and annotation system. Nucleic Acids Res. 2015;43:D1064-70.

46. Araujo FA, Barh D, Silva A, Guimarães L, Ramos RT. GO FEAT: a rapid webbased functional annotation tool for genomic and transcriptomic data. Sci Rep. 2018;8:1-4.

47. Kumar N, Skolnick J. EFICAz2. 5: application of a high-precision enzyme function predictor to 396 proteomes. Bioinformatics. 2012;28:2687-8.

48. Elbourne LD, Tetu SG, Hassan KA, Paulsen IT. TransportDB 2.0: a database for exploring membrane transporters in sequenced genomes from all domains of life. Nucleic Acids Res. 2017:45:D320-4.

49. Ashburner M, Ball CA, Blake JA, Botstein D, Butler H, Cherry JM, Davis AP, Dolinski K, Dwight SS, Eppig JT, Harris MA. Gene ontology: tool for the unification of biology. Nat Genet. 2000;25:25-9.

50. Mitchell A, Chang HY, Daugherty L, Fraser M, Hunter S, Lopez R, McAnulla C, McMenamin C, Nuka G, Pesseat S, Sangrador-Vegas A. The InterPro protein families database: the classification resource after 15 years. Nucleic Acids Res. 2015;43:D213-21

51. Lima T, Auchincloss AH, Coudert E, Keller G, Michoud K, Rivoire C, Bulliard V, De Castro E, Lachaize C, Baratin D, Phan I. HAMAP: a database of completely sequenced microbial proteome sets and manually curated microbial protein families in UniProtKB/Swiss-Prot. Nucleic Acids Res. 2009;37:D471-8.

52. Duvaud S, Gabella C, Lisacek F, Stockinger H, loannidis V, Durinx C. Expasy, the Swiss Bioinformatics Resource Portal, as designed by its users. Nucleic Acids Res. 2021. https://doi.org/10.1093/nar/gkab225.

53. Kanehisa M, Goto S. KEGG: kyoto encyclopedia of genes and genomes. Nucleic Acids Res. 2000;28:27-30.

\section{Publisher's Note}

Springer Nature remains neutral with regard to jurisdictional claims in published maps and institutional affiliations.

Ready to submit your research? Choose BMC and benefit from:

- fast, convenient online submission

- thorough peer review by experienced researchers in your field

- rapid publication on acceptance

- support for research data, including large and complex data types

- gold Open Access which fosters wider collaboration and increased citations

- maximum visibility for your research: over $100 \mathrm{M}$ website views per year

At BMC, research is always in progress.

Learn more biomedcentral.com/submissions 